R. P. Campbell

R. D. Dixon

A. L. Liby

Fabrication Technology

JOINING GROUP

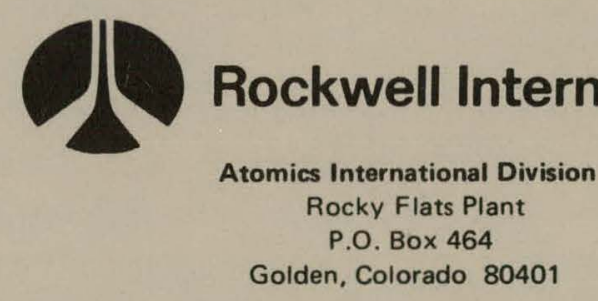

U. S. DEPARTMENT OF ENERGY CONTRACT EY-76-C-04-3533 


\section{DISCLAIMER}

This report was prepared as an account of work sponsored by an agency of the United States Government. Neither the United States Government nor any agency Thereof, nor any of their employees, makes any warranty, express or implied, or assumes any legal liability or responsibility for the accuracy, completeness, or usefulness of any information, apparatus, product, or process disclosed, or represents that its use would not infringe privately owned rights. Reference herein to any specific commercial product, process, or service by trade name, trademark, manufacturer, or otherwise does not necessarily constitute or imply its endorsement, recommendation, or favoring by the United States Government or any agency thereof. The views and opinions of authors expressed herein do not necessarily state or reflect those of the United States Government or any agency thereof. 


\section{DISCLAIMER}

Portions of this document may be illegible in electronic image products. Images are produced from the best available original document. 


\section{LEGAL NOTICE}

This report was prepared as an account of work sponsored by the United States Government. Neither the United States nor the Department of Energy, nor any of their employees, nor any of their contractors, subcontractors, or their employees, makes any warranty, expressed or implied, or assumes any legal liability or responsibility for the accuracy, completenesss or usefulness of any information, apparatus, product or process disclosed, or represents that its use would not infringe privately owned rights.

Printed in the United States of America

Available from the

National Technical Information Service

II. S. Department of Commerce

Springfield, Virginia 22161

Price: Printed Copy $\$ 5.00$ Microfiche $\$ 3.00$

Price Is Subject to Change Without Notice 
Printed

January 1,1978
RFP-2621

UC-25 MATERIALS

TID-4500-R66

\section{ELECTRON-BEAM FUSION WELDING OF BERYLLIUM}

R. P. Campbell

R. D. Dixon

A. L. Liby

Fabrication Technology JOINING GROUP
This report wat prepared as an account of work sponsored by the United Siates Govemment. Neither the Undred States nor the United States Department of Energy, nor any of their employees, nor any of their contractors, subcontractor, of their employees, inter sny warranty, express or implied, or assumes any lesel liability or responsibility for the accuracy, completeness or usefulness of any information, appunius, produet or process disclosed, of represents that its use product or infringe privately orned resents that its use would not

\section{SUBJECT DESCRIPTORS}

Beryllium

Electron Beam Welding

Matcrials Testing

ROCKWELL INTERNATIONAL

ATOMICS INTERNATIONAL DIVISION

ROCKY FLATS PLANT

P. O. BOX 464

GOLDEN, COLORADO. 80401

Prepared under Contract EY-76-C-04-3533

for the

Albuquerque Operations Office

United States Department of Energy 
RFP-2621

\section{THIS PAGE \\ WAS INTENTIONALLY \\ LEFT BLANK}




\section{CONTENTS}

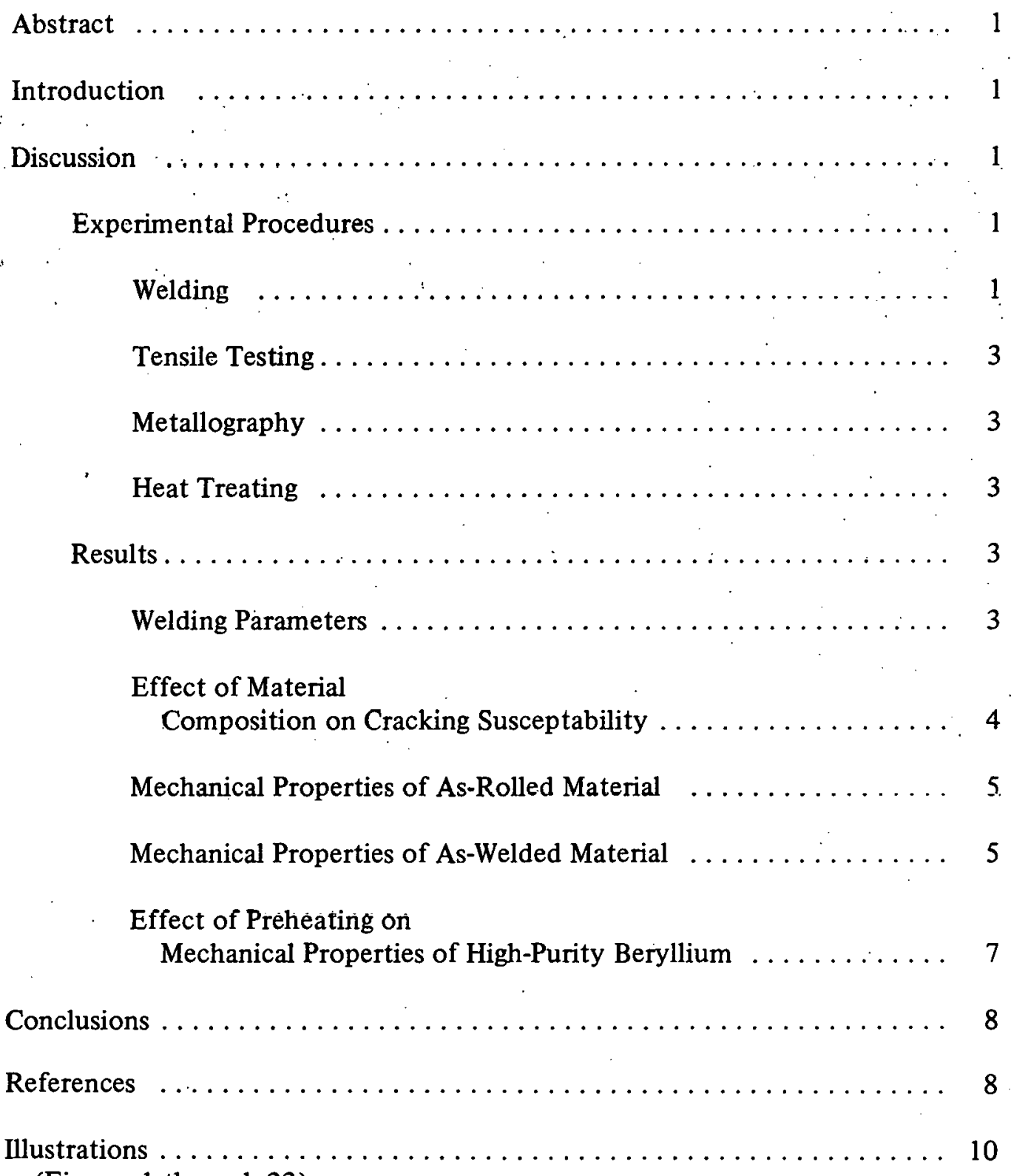

(Figures 1 through 23) 


\section{ACKNOWLEDGEMENTS}

The authors thank the staff of the General Metallurgy machine shop for their cooperation in machining weld specimens and tensile bars and for performing the heat treating operations. Appreciation is also expressed to the Nondestructive Testing staff for their timely inspection of all the samples. In particular, we wish to acknowledge the efforts of Mr. W. W. Leslie for obtaining the material, for his help in completing the tensile testing, and for his suggestions. 


\title{
ELECTRON-BEAM FUSION WELDING OF BERYLLIUM
}

\author{
R. P. Campbell, R. D. Dixon, and A. L. Liby
}

\begin{abstract}
Ingot-sheet beryllium (Be) having three different chemistries and three different thicknesses was fusion-welded by the electron-beam process. Several different preheats were used to obtain 100 percent penetration and crack-free welds. Cracking susceptability was found to be related to aluminum (Al) content; the higher Al-content material was most susceptable. However, adequate preheat allowed full penetration and crack-free welds to be made in all materials tested.

The effect of a post-weld heat treatment on the mechanical properties of these compositions was also determined. The heat treatment produced no significant effect on the ultimate tensile strength. However, the yield strength was decreased and the ductility was increased. These changes are attributed to the formation of $\mathrm{AlFeBe}_{4}$ and $\mathrm{FeBe}_{11}$.
\end{abstract}

\section{INTRODUCTION}

Ingot-sheet beryllium ( $\mathrm{Be})$ is a cast and rolled material developed at Rocky Flats as an economical way to recycle scrap $\mathrm{Be}$ originally produced by powder-metallurgy techniques. The use of ingotsheet $\mathrm{Be}$, for many applications, depends upon its weldability. It exhibits better weldability than powder-metallurgy material in both braze and fusion-welding processes $(1,2,3) .{ }^{1}$ The improved weldability is attributed primarily to a lower beryllium oxide $(\mathrm{BeO})$-content than that of powdermetallurgy source material (3).

Presently, gas-metal-arc braze welding, using an aluminum-12 percent silicon filler metal, is the most frequently used method of joining Be at Rocky Flats. With this technique, 100 percent joint efficiencies have been obtained in 6.3-millinetre $(\mathrm{mm})$ thick material without preheating (2).

Both ingot-sheet and powder-source Be have been fusion-welded by gas-tungsten-arc and electron-beam methods. However, very careful control of heat input and joint restraint, along with preheating,

\footnotetext{
'Numbers in parentheses refer to references at end of text.
}

were required to produce crack-free welds $(3,4,5$, $6,7,8)$. These welds have generally exhibited low as-welded strength and elongation which are attributed to microcracks, large fusion grains, and non-optimum distribution of impurities in the fusion and heat-affected zones.

The purpose of this investigation was to first study the effect of chemical composition of ingot-sheet $\mathrm{Be}$ on electron-beam weldability and the response of the different compositions to a post-weld heat treatment; and second, to study the effect of preheating on weld microstructure and strength.

\section{DISCUSSION}

\section{Experimental Procedures}

Beryllium from three different ingots was used in this investigation. The materials were selected on the basis of their aluminum (Al) and iron (Fe) content, which is known to affect weldability and mechanical properties $(4,9)$. The compositions of the three materials are shown in Table I. Materials $A$ and $B$ are normal-purity Rocky Flats ingot-sheet $\mathrm{Be}$, while Material $\mathrm{C}$ is a special high-purity material. The material was supplied in 75 by $50 \mathrm{~mm}$ and 90 by $75 \mathrm{~mm}$ coupons, with thicknesses of 1.40 , 1.90 , and $2.50 \mathrm{~mm}$.

Ingot-sheet $\mathrm{Be}$ is vacuum-cast; then reduced by can-rolling, followed by bare-rolling to the desired thickness. The coupons were received in the asrolled condition. This was a duplex structure, resulting from insufficient reduction during the hot breakdown and final canned-rolling stages for Material A and B, and a typical warm-worked structure for Material C (10).

\section{Welding}

All welding was done with a 7.5 kilowatt $(\mathrm{kW})$ high voltage Hamilton Standard electron-beam welder. 
TABLE I. Analysis of Ingot Sheet Beryllium...

Material A

Lot No. 503951-N

(weight percent)

Beryllium (Be) (Assay)

Beryllium Oxide (BeO)

Aluminum (Al)

Iron $(\mathrm{Fe})$

Carbon (C)

Silicon (Si)

Titanium (Ti)

Coppor $(\mathrm{Cu})$

Mánganese (Mñ)

Nickel (Ni)

Zinc (2n)

Nitrogen $(\mathrm{N})$

Chromium (Cr)

Calcium (Ca)

Molybdenum (Mo)

Cadium (Cd)

Cobalt (Co)

Magnesium (Mg)

\subsection{8}

$a<0.010$

b $\quad 0.071$

b 0.135

b 0.076

0.034

0.020

0.018

0.016

0.014

0.010

b 0.006

0.005

$<0.003$

$<0.003$

$<0.001$

$<0.001$

$<0.001$
Material B

Lot No. 503942-S

(weight percent)

\subsection{3}

$a_{<} 0.010$

b 0.040

b 0.134

b 0.054

0.024

0.020

0.013

0.012

0.022

0.010

0.030

$<0.003$

$<0.003$

$<0.001$

$<0.001$

$<0.001$
Material C

Lot No. 40Cr High-Purity

(weight percent)

99.87

$a_{<}<0.010$

b $\quad 0.029$

b 0.022

b $\quad 0.055$

0.018

$<0.001$

$0.01 \mathrm{it}$

$b_{<} 0.003$

0.008

$<0.010$

b $\quad 0.004$

$<0.002$

$<0.003$

$<0.003$

$<0.001$

$<0.001$

$<0.001$

${ }^{a}$ Not analyzed; typical composition of ingot sheet used.

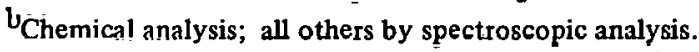

Due to the toxicity of airborne Be particles, the welder was equipped with a special exhaust system to prevent contamination of the operator and the release of $\mathrm{Be}$ particles into the atmosphere.

Full penetration bead-on-plate welds were used throughout the investigation. Bead-on-plate welds were used rather than butt welds to eliminate factors such as joint preparation, fit-up, and beam alignment. Weld coupons 75 by $50 \mathrm{~mm}$ were used for the development of welding parameters and the investigation of cracking susceptability, while 90 by $75 \mathrm{~mm}$ coupons were used for tensile specimens. All coupons were etched with a solution of 2 percent hydrofluoric acid (HF), 48 percent nitric acid $\left(\mathrm{HNO}_{3}\right)$, and 50 percent water $\left(\mathrm{H}_{2} \mathrm{O}\right)$. to remove surface oxides. The coupons were also cleaned with acetone before welding to remove any grease or other contamination present.
During welding, the coupons were securely held in a fixture having resistance heating elements to provide preheat temperatures of up to $500{ }^{\circ} \mathrm{C}$. The preheat temperature was measured with two thermocouples placed between the weld coupon and the fixture. Beryllium run-off tabs were used to permit welding the entire length of the coupon and to eliminate crater-cracking in the coupon at the start and finish of the weld. All coupons were placed in the fixture so that the welds were made parallel to the final rolling direction of the material.

The welds were made with the electron beam sharply focused on the top surface of the coupon being welded. Focussing above and below the top surface, defocussing of the beam, and use of the high frequency beam-deflection system were tried, but showed no advantage over a sharp focus on the top surface. The welder gun-to-work distance was 
$150 \mathrm{~mm}$ for all of the welds. The vacuum during welding ranged from $1.6 \times 10^{-2}$ to $1.0 \times 10^{-2}$ pascals, with most of the welds made at a pressure of $1.3 \times 10^{-2}$ pascals. Lower pressures were avoided to prevent excessive vaporization of the $\mathrm{Be}$, which would result in severe undercutting.

\section{Tensile Testing}

Tensile specimens were machined from the 90 - by 75- $\mathrm{mm}$ weld coupons. The specimens were cut transverse to the full penetration bead-on-plate weld and thus were normal to the final rolling direction of the sheet. Tensile specimens were also machined from coupons without welds to determine the asrolled material properties. The dimensions of the tensile specimen's used are shown in Figure 1, appearing at the end of the text.

Due to surface damage, as a result of machining, the tensile specimens were either etched or annealed before testing to give consistent results. The heattreated specimens were not etched since annealing removes machining damage from carefully machined surfaces. Annealing yields results consistent with those of specimens which have approximately 0.1 $\mathrm{mm}$ of material removed from each surface by etching (11). The weld face and root surfaces were left. as welded.

Tensile testing was performed on a universal testing machine equipped with a vacuum furnace set at $600{ }^{\circ} \mathrm{C}$. All of the tests were made with a constant crosshead speed of 0.51 millimetres per minute. The 0.2 percent of fset yield strength and elongation were determined from the load-time curves for each test.

To detect any cracking or porosity present in the weld or heat-affected zones, radiographic and dyepenetrant inspections were performed on the welds from which tensile specimens were machined.

\section{Metallography}

Selected welds were metallographically prepared to examine the fusion-zone shape and grain structure. Sections were taken transverse to the weld. The polished specimens were observed without etching under both polarized and white light. The polarized light was used to show the weld shape and grain
TABLE II. Electron Beam Welding Conditions for Crack-Free Full Penetration Bead-On-Plate Welds.

\begin{tabular}{|c|c|c|c|c|c|c|}
\hline \multirow{2}{*}{$\begin{array}{l}\text { Thickness } \\
(\mathrm{mm})\end{array}$} & \multirow{2}{*}{$\begin{array}{c}\text { Voltage } \\
(\mathrm{kV})\end{array}$} & \multirow{2}{*}{$\begin{array}{c}\text { Current } \\
(\mathrm{mA})\end{array}$} & \multirow{2}{*}{$\begin{array}{c}\text { Travel Speed } \\
(\mathrm{mm} / \mathrm{sec}) \\
\end{array}$} & \multicolumn{3}{|c|}{$\begin{array}{c}\text { Preheat } \\
\left({ }^{\circ} \mathrm{C}\right) \\
\text { (Materials) }\end{array}$} \\
\hline & & & & $\mathbf{A}$ & B & $\mathrm{C}$ \\
\hline 2.50 & 110 & 7.5 & 8.5 & 400 & 260 & $a_{260}$ \\
\hline 1.90 & 100 & 7.0 & 8.5 & 400 & 260 & $a_{120}$ \\
\hline \multirow[t]{2}{*}{1.40} & 90 & 5.0 & 8.5 & 175 & 120 & None \\
\hline & \multicolumn{6}{|c|}{$\begin{array}{l}{ }^{a} \text { Necessary to give regular penetration and } \\
\text { prevent severe undercutting. }\end{array}$} \\
\hline
\end{tabular}

structure, while the white light was used to detect any microcracking or porosity in the weld.

\section{Heat Treating}

Some of the tensile specimens were given an aging heat treatment before testing to determine possible effects of precipitation on the weld properties. Materials A and B were heat treated in a vacuum furnace at $780^{\circ} \mathrm{C}$ for 4 hours, while Material $\mathrm{C}$ was heat treated at $727^{\circ} \mathrm{C}$ for 4 hours, followed by a furnace cool. The higher purity material was heat treated at a lower temperature to prevent excessive grain growth.

\section{Results}

\section{Welding Parameters}

The initial welding parameters used in the investigation were developed during previous work done at Rocky Flats on electron-beam fusion welding of ingot-sheet $\mathrm{Be}(12)$. Only slight changes were required in these parameters to successfully produce full penetration bead-on-plate welds. Full penetration welds were used in the investigation because partial penetration welds were not as susceptable to cracking and could not be used for tensile testing without machining. The final welding parameters, along with the preheats required to produce crack-free welds, are shown in Table II.

For the three materials studied, it was necessary to preheat the $2.50-\mathrm{mm}$ thick specimens to produce a smooth weld underbead having constant penetration. Further, welds made without sufficient preheat 
RFP-2621 .

TABLE III. Relationship Between Cracking Susceptability and Impurity Content of Electron-Beam Wclded Ingot Sheet Beryllium.

\begin{tabular}{|c|c|c|c|}
\hline Impurity & Material A & Material B & ${ }^{{ }^{M} \text { Material C }}$ \\
\hline $\begin{array}{l}\text { Aluminum } \\
\text { (Al) }\end{array}$ & 710 & 400 & 290 \\
\hline $\begin{array}{c}\text { Silicon } \\
\text { (Si) }\end{array}$ & 340 & 240 & 180 \\
\hline $\begin{array}{l}\text { Titanium } \\
\text { (Ti) }\end{array}$ & 200 & 200 & 20 \\
\hline $\begin{array}{l}\text { Aluminum + Silicon + Titanium } \\
(\mathrm{Al}+\mathrm{Si}+\mathrm{Ti})\end{array}$ & 1250 & 840 & 490 \\
\hline$\underset{(\mathrm{Fe})}{\operatorname{Iron}} \cdot$ & 1350 & 1340 & 220. \\
\hline $\begin{array}{l}\text { Iron/Aluminum } \\
(\mathrm{Fe} / \mathrm{Al})\end{array}$ & 1.90 & 3.35 & 0.76 \\
\hline
\end{tabular}

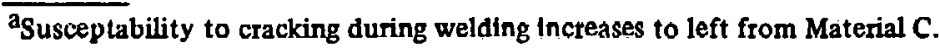

exhibited severe undercutting. Crack-free welds could be made in the high-purity material without preheating the $1.90-$ and $2.50-\mathrm{mm}$ specimens using higher heat inputs than those shown in Table II. However, the underbeads were very jagged and the penetration varied from insufficient to excessive along the welds. Preheating promoted undercut-free welds with smooth underbeads in all three materials. Figure 2 shows typical weld face and root surfaces obtained in the $2.50-\mathrm{mm}$ material.

Material composition apparently did not affect the weld shape and penetration. Therefore, the same welding parameters were used on the three base materials of the same thickness. Typical micrographs of welds made in the 1.40 - and $2.50-\mathrm{mm}$ thick materials are shown in Figures 3 through 8 .

\section{Effect of Material Composition on Cracking Susceptability}

i The effect of material composition on cracking susceptability was investigated by determining the preheat required to produce crack-free welds. Full penetration bead-on-plate welds were made in the three materials with thickness of $1.40,1.90$, and $2.50 \mathrm{~mm}$. Preheats of room temperature, 120, 175, 260 , and $400{ }^{\circ} \mathrm{C}$ were used to determine which preheat would prevent cracking.
Crack-free welds were those that contained no visible surface cracks when observed at magnification $4 \mathrm{X}$, using a stereo microscope. Dye-penetrant and radiographic inspections revealed no cracks that were not found by visual inspection. Metallographic examination of selected welds showed microcracking only in the welds found to contain visible cracks. Two types of cracks were observed in the welds: transverse and centerline. The transverse cracks originated in the base material near the fusion-zone boundary and propagated into the fusion zone at approximately a 45 degree angle to the direction of welding. A typical transverse crack is shown in Figure 9. Centerline cracks ran longitudinally along the center of the weld and were observed only in welds having a severe crack on the surface.

'The three materials are ranked according to their cracking susceptability during welding as shown in Table III. This ranking is based on the preheat required to prevent cracking as shown in Table 11 . No cracking occurred in Material $C$ throughout the investigation, while cracking in Materials $\mathrm{A}$ and $\mathrm{B}$ varied from severe to none, depending on the thickness and the preheat.

Cracking susceptability of the three materials was found to be directly related to the $\mathrm{Al}$ content. This is probably due to the formation of low meltingpoint.Al phases in the grain boundaries, which is 
known to promote hot cracking $(4,13)$. Liquid $\mathrm{Al}$ has been observed at the grain boundaries in $\mathrm{Be}$ heated in the range of 400 to $500{ }^{\circ} \mathrm{C}(14,15)$. Also, previous work with gas-tungsten-arc welded powder-source Be has shown hot cracking to be related to the Al content (4).

This agrees with studies showing that aluminum-rich precipitates are formed in the grain boundaries of ingot-sheet $\mathrm{Be}$ rapidly cooled from $900{ }^{\circ} \mathrm{C}(16,17$, 18). Further, aluminum-rich precipitates have been found at intergranular cracks in electron-beam welded ingot sheet $\mathrm{Be}(3,13)$.

Silicon ( $\mathrm{Si}$ ) and titanium (Ti) have also been observed at intergranular cracks in both $\mathrm{Be}$ welds and ingots $(3,19)$. Silicon and Ti might also contribute to hot cracking in Be welds. However, the Si and Ti contents of the three base materials were related in the same way as the $\mathrm{Al}$ contents; therefore, determining which impurity has the greatest effect would be difficult.

\section{Mechanical Properties of As-Rolled Material}

The microstructure of as-rolled and of heat-treated specimens from each material used in this investigation is shown in Figures 10 and 11. Table IV and Figure 12 show tensile strength data for these materials. The ultimate tensile strength measured at room temperature for all materials was reduced by heat treatment as shown in Figure 12. This strength reduction was not significant in the $600{ }^{\circ} \mathrm{C}$ tensile tests. As expected, the strain-free heattreated material had a significantly lower yield strength, as indicated in Table IV.

The room-temperature ductility was approximately equal for all three materials in the as-rolled condition. The room-temperature ductility of Material B increased, while that of Materials A and C decreased following heat treatment, as shown in Figure 13. The ductility of ingot-sheet Be typically increases following annealing heat treatment $(18,20)$. The anomalous behavior for materials $\mathrm{A}$ and $\mathrm{C}$ may have resulted from the increase in grain size with heat treatment. Grain size of each material measured before and after heat treatment is shown in Table V.
Elongations measured at a testing temperature of $600^{\circ} \mathrm{C}$ are shown in Figure 14. The measured values vary quite widely with trends for the asrolled and heat-treated materials having opposite slopes. The failure mode at $600{ }^{\circ} \mathrm{C}$ is known to be affected by metallic impurity level of the Be. material. Low-melting aluminum-rich phases at grain boundaries may cause intergranular failure with low ductility. Absence of these low-melting phases gives rise to fibrous transgranular failures with relatively high elongations (9). In the asrolled condition, the grain boundaries are rich in $\mathrm{Al}$, and the matrix rich in iron (Fe). As-rolled hightemperature ductility would be expected to relate to $\mathrm{Al}$ content. As shown in Figure 14, the lowaluminum Material $\mathrm{C}$ shows the highest elongation. However, ductilities measured for Materials $\mathrm{A}$ and $\mathrm{B}$ do not correlate with total $\mathrm{Al}$ content.

In the heat-treated condition, the high-temperature ductility of Material $C$ decreases, while that of Materials A and B increases. This effect probably results from the opposing factors of grain growth and impurity element redistribution. The ductility of Material $\mathrm{C}$ is decreased because of grain growth, while the ductilities measured for Materials $\mathrm{A}$ and $B$ increase after heat treatment because $F e$ has migrated to the grain boundaries to combine with the low-melting $\mathrm{Al}$ phases to form the ternary compound $\mathrm{FeAlBe}_{4}$. Material $\mathrm{B}$ shows the strongest response to heat treatment owing to its higher $\mathrm{Fe}$ - to $\mathrm{Al}$ - ratio.

\section{Mechanical Properties of As-Welded Material}

The ultimate tensile strengths of all three materials, tested at room temperature and at $600{ }^{\circ} \mathrm{C}$ (Figure 12), were not significantly different for the aswelded and the welded and heat-treated conditions. The post weld heat treatment did however decrease the yield strength and increase the tensile elongation. The tensile specimens tested at room temperature all failed in the weld zone, while the majority of the specimens failed in the base metal when tested at $600^{\circ} \mathrm{C}$. Also, the specimens tested at room temperature exhibited low elongations, as shown in Figure 15, since the weld reinforcement limited the amount of necking that could occur. 
TABLE IV. Average Tensile Data for Electron Beam Welded $1.40 \mathrm{~mm}$ Thick Ingot Sheet Beryllium.

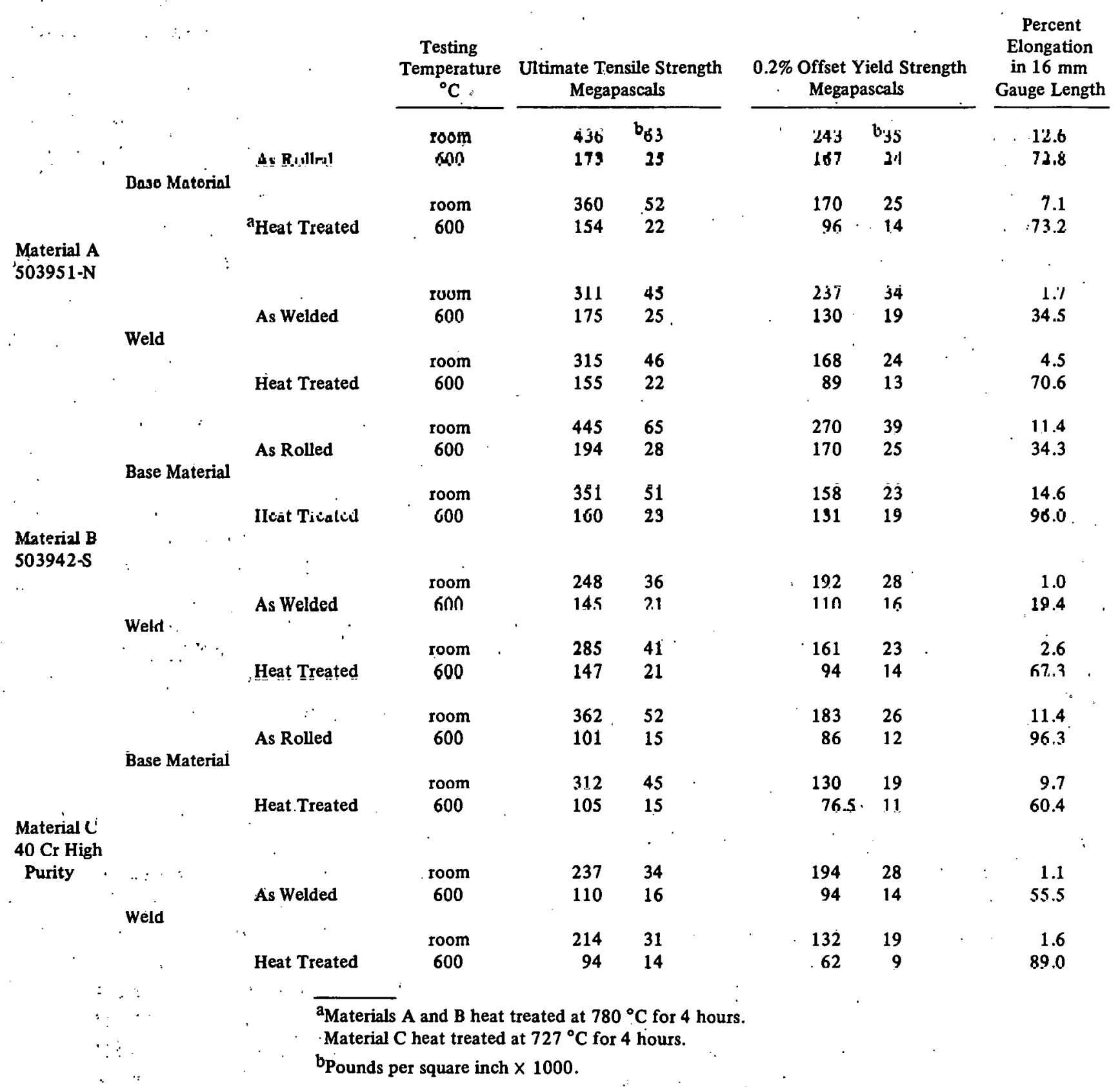


TABLE V. Grain Size Resulting from Heat Treatment.

\begin{tabular}{|c|c|c|c|}
\hline Material & Heat Treatment & Test Temperature & $\begin{array}{c}\text { ASTM } \\
\text { Grain Size }\end{array}$ \\
\hline $\mathbf{A}$ & no & room & 7 \\
\hline$\therefore \mathrm{A}$ & yes & room & 5 \\
\hline $\mathbf{A}$ & no : & $600^{\circ} \mathrm{C}$ & 8 \\
\hline$A$ & yes & $600^{\circ} \mathrm{C}$ & 6 \\
\hline B & "nó & room & 8 \\
\hline B & yes & room & 6 \\
\hline B & no & $600^{\circ} \mathrm{C}$ & 8 \\
\hline B & yes & $600^{\circ} \mathrm{C}$ & 6 \\
\hline $\mathrm{C}$ & no & room & 7 \\
\hline$C$ & yes & room & 5 \\
\hline $\mathrm{C}$ & no & $600^{\circ} \mathrm{C}$ & 7 \\
\hline $\mathrm{C}$ & yes & $600^{\circ} \mathrm{C}$ & 6 \\
\hline
\end{tabular}

The elongations of welded specimens, when tested at room temperature, are nearly the same and significantly less than those obtained in the asrolled condition.

The increase in elongation of weld specimens after heat treating is attributed to the formation of the precipitates $\mathrm{AlFeBe}_{4}$ and $\mathrm{FeBe}_{11},{ }^{2}$ as well as to homogenization. Upon welding, with no preheating, regions in the fusion-and heat-affected zones are cooled rapidly enough to prevent the precipitation reaction from occurring (13). Hence, the Fe remains in solution, resulting in solid-solution hardening which, in turn, produces the higher yield strength and the lower ductility in the as-welded condition (21). Heat treating or aging at temperatures between 700 and $800^{\circ} \mathrm{C}$ allows solute diffusion to occur, forming the precipitates $\mathrm{AlFeBe}_{4}$ and $\mathrm{FeBe}_{11}$ (18). Some evidence also exists that formation of the precipitates ties up the matrix $\mathrm{Fe}$ along with the free $\mathrm{Al}$ in the grain boundaries resulting in improved ductility and decreased strength (9). The improvement in elongation of the welded specimens as a result of the heat treatment is shown in Figure 16.

\footnotetext{
${ }^{2}$ Actual formulas are $\mathrm{AlMBe}_{4}$ and $\mathrm{MBe}_{11}$, where $\mathrm{M}$ represents Fe. Mn. Ni, or S.r. Since Fe is present, in the greatest amount, it is used in place of $M$.
}

As seen in Figure 15, the heat treatment produced larger improvements in elongation for the lowpurity Materials A and B, while having a smaller effect on the high-purity Material C. This is the result of the homogenization of Materials A and B. Also, because the low-purity materials showed greater response to a precipitation reaction due to a greater amount of impurities available for redistribution within the material. While precipitation has been found to occur in higher purity materials, the effect on mechanical properties was less than that for low purity materials $(9,22)$.

From Figure 16 it is noted that the material with the highest $\mathrm{Al}$ content displays the most improved elongation. This is probably due to the different preheats used. The preheat used for Material A was $50{ }^{\circ} \mathrm{C}$ greater than that used for Material B. This allowed more time for diffusion and would permit more $\mathrm{Fe}$ to combine with the $\mathrm{Al}$; thus, decreasing the free Al. Subsequent heat treatment would allow the precipitates to coalesce at the grain boundries as well as allow the formation of more precipitates: An elongation slightly higher than that of a lower $\mathrm{Al}$ impurity material could thus be obtained.

The elongation values obtained from as-welded and heat-treated specimens at a testing temperature of $600{ }^{\circ} \mathrm{C}$ are shown in Figure 17. As previously. stated, many of these samples failed in the parent . metal. These include all of the heat-treated and the unheat-treated samples from Material C. The increase in elongation of the low-purity materials is again attributed to the formation of the precipitate $\mathrm{AlFeBe}_{\boldsymbol{A}}$ during both post-weld quench and post-weld heat treatment, as.well as the reduction from a duplex structure to a uniform grain size. The difference in preheat is again seen in these data. The high elongation of Matcrial $\mathrm{C}$ is probably the result of recrystalization of the fusion- and heat-affected zones, although small amounts of impurities will influence the mechanical properties.

Effect of Preheating On Mechanical Properties of High-Purity Beryllium

Full penetration bead-on-plate welds were made on 1.90-mm thick coupons of Material C. Welding 
parameters of 100 kilovolts $(\mathrm{kV}), 7$ milliamperes $(\mathrm{mA})$, and 8.5 millimetres per second $(\mathrm{mm} / \mathrm{sec})$ were used, with preheats of room temperature, 175 and $400^{\circ} \mathrm{C}$. An additional weld was made with a preheat of $400{ }^{\circ} \mathrm{C}$, using welding parameters of $100 \mathrm{kV}, 5 \mathrm{~mA}$, and $8.5 \mathrm{~mm} / \mathrm{sec}$. Visual inspection, radiography, and dye penetrant inspection did not reveal any cracking in the welds. All of the tensile specimens received a 4-hour heat treatment of $727^{\circ} \mathrm{C}$ before testing.

Welds made with higher preheat temperatures were found to have a wider fusion zone with a larger fusion-zone grain size and greater grain growth in the heat-affected zone, as shown in Figures 18 through 21 . The higher preheat produces a greater total heat input and a lower thermal gradient outward from the centerline of the weld. This results in larger fusion-zone grain size upon solidification and more grain growth in the heataffected zone.

The results of the tensile testing are shown in Figure 22. The ultimate tensile strength and elongation of the welds made with the room temperature preheat were slightly higher than for the welds made with the 175 and $400^{\circ} \mathrm{C}$ preheats. There was no significant difference in the strength and elongation of the welds made with the 175 and $400^{\circ} \mathrm{C}$ preheats or the two welds with different heat inputs, even though a large difference in fusion-zone size and grain size existed. The fracture path in the fusion zone generally followed the weld centerline, as shown in Figure 23. Therefore, the structure along the weld centerline may have a greater effect on strength and ductility than the fusion-zone size and the grain size. The weld made with a room temperature preheat had slightly better strength and elongation because it displayed a more favorable grain orientation and morphology at the weld centerline than did the welds made with the higher preheats.

\section{CONCLUSIONS}

Sound fusion welds have been made in flat-ingot sheet Be specimens from 1.40- to 2.50-mm thickness using the electron-beam welding process. Preheating was found to promote weldability. Preheating was required to produce crack-free welds in specimens of higher aluminum impurity level and thicker cross section.

Elongation of welded specimens was improved by a post-weld aging heat treatment in the 700 to $800^{\circ} \mathrm{C}$ temperature range. This aging treatment allows migration of $\mathrm{Fe}$ to the fusion zone grain boundaries so that it combines with aluminum-rich phases to form the ternary compound $\mathrm{FeAlBe}_{4}$. As expected, specimens with the highest $\mathrm{Fe}$-to-Al ratio showed the greatest post-weld aging response.

\section{REFERENCES}

1. G. K. Hicken and W. B. Sample; Jr. "Joining Beryllium by an Electron Beam Braze Welding Technique." Welding Journal. 541-S:550-S, Vol 46, No. 12. 1967.

2. R. J. Merlini and W. L. Bush. Gas-Metal Braze Welding of Ingot-Sheet Beryllium. RFP-1333. Rocky Flats Division, The Dow Chemical Company, Golden, Colorado. 1969.

3. D. Hausen and R. E. Monroe. "Electron Beam Welding of Beryllium-Part 'Two." Welding Journal. 497-S:514-S, Vol 4\%. No. 11. 1968.

4. E. M. Passmore. "Fusion Welding of Beryllium." Welding Juurmal. 116=S:124-S, Vol 43, No 3. 1964.

5. D. G. Scott, C. L. Estes, R. A. Huber, and P. W. Turner. "Joining of Beryllium." WeldJournal. 15:23, Vol 51, No. 1. 1972.

6. S. S. White, H. J. Landen, W. T. Hess, and R. Bakish. "A Study of Electron Beam Welding." Welding Journal. 279-S:336-S, Vol 41, No. 7. 1962.

7. D. Hauser, H. W. Mishler, R. E. Monroe, and D. C. Martin. "Electron Beam Welding of Beryllium." Welding Journal. 525-S:540-S, Vol 46, No. 12. 1967.

8. T. J. McDonald, N. F. Eaton, and D. B. Wright. "Fusion Welding of Beryllium." British Welding Journal. 441:450, No. 7. 1960. 
9. S. H. Gelles. "Impurity, Effects in Beryllium." Metals and Ceramic Information Center. MCIC-72-06. March, 1972.

10. J. L. Frankery and D. R. Floyd, Ingot-Sheet Beryllium Fabrication. RFP-910. Rocky Flats Division, The Dow Chemical Company, Golden, Colorado. 1968.

11. S. Beitscher. Tensile Properties of Rocky Flats Division Ingot-Sheet Beryllium from Room Temperature to $250^{\circ} \mathrm{C}$. RFP-1205. Rocky Flats Division, The Dow Chemical Company, Golden, Colorado. 1968.

12. A. L. Liby and R. Jamscy, Jr. Rocky Flats Division, The Dow Chemical Company, Golden, Colorado. Unpublished communication. 1974.

13. F. J. Fraikor, G. K. Hicken, and V. K. Grotzky. Precipitation in Electron Beam Welded Beryllium Ingot Sheet. RFP-1112. Rocky Flats Division, The Dow Chemical Company, Golden, Colorado. 1968.

14. M. Weisz, J. Mallen, and J. L. Varon. "Possibility of the Appearance of A Liquid Phase at $430^{\circ}$.C in Commercial Beryllium." Journal of Nuclear Materials. 56:59, Vol 10, No. 1. 1963.

15. P. Bastien and P. Pointu. "Microscopic Examination of Beryllium While Being Deformed in the Hot-Shorted Region." Journal of Nuclear Materials. 63:66, Vol 10, No. 1. 1963.

16. F. J. Fraikor and V. K. Grotzky. Transactions, American Institute of Mechanical Engineers.
"Grain Boundary Precipitation in Sheet Rolled from Beryllium Ingots." 2008:2010, Vol 239, No. 12. 1967.

17. F. J. Fraikor and A. W. Brewer. Transactions, American Society of Metals. "Precipitation in Quenched and Aged Beryllium Ingot Sheet." 784:788, Vol 61. 1968.

18. F. J. Fraikor, V. K. Grotzky, A. W. Brewer, and H. E. Reed. Precipitation Characteristics of Rocky Flats Beryllium Ingot Sheet. RFP-1041. Rocky Flats Division, The Dow Chemical Company, Golden, Colorado. 1968.

19. R. Goosey, R. A. Knight, and A. J. Martin. "The Induction Melting and Casting of Beryllium." Journal of the Less Common Metals. 199:212, Vol 4. 1962.

20. D. R. Floyd. Development and Pilot Production of Three Ingot-Source Beryllium Sheet Metal Parts. RFP-1827. Rockwell International, Rocky Flats Plant. 1975.

21. F. M. Yans, A. D. Donaldson, and A. R. Kaufmann. "The Effect of Copper, Nickel, Iron, and Chromium on the Tensile Properties of Perferentially Oriented Beryllium Sheet." Transaction, American Institute of Mechanical Engincers. 364:370, Vol 221, No. 4. 1961.

22. A. B. Brown, F. Morrow, and A. J. Martin. "The Effect of Strain Rate and Heat Treatment on the Tensile Properties of Extruded Beryllium Rods Between 25 and $600^{\circ} \mathrm{C}$." Journal of the Less Common Metals. 62:88, Vol 3. 1961. 
RFP-2621

\section{L L U S T R A T I O N S}

(Figures 1 through 23) 


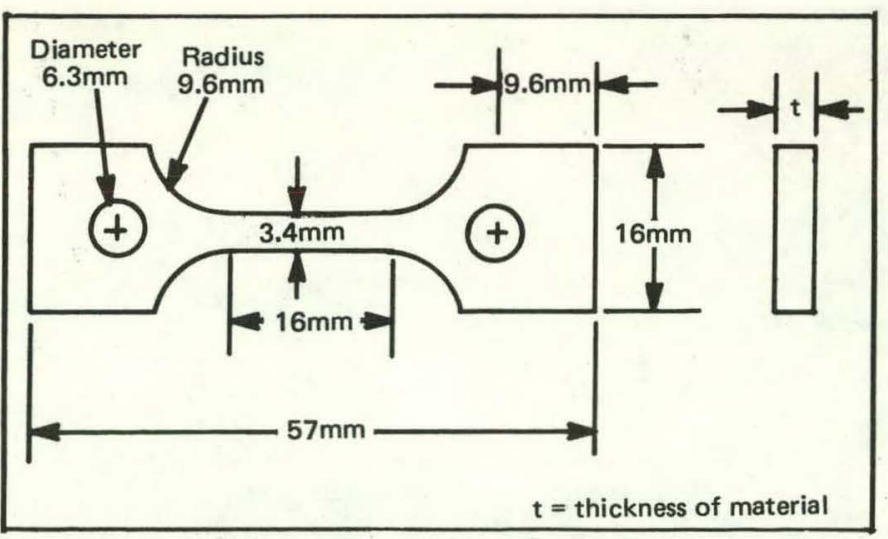

FIGURE 1. Tensile Specimen Geome-

try. Dimensions are in millimetres.

FIGURE 2(a) and (b). Typical Weld Surfaces.

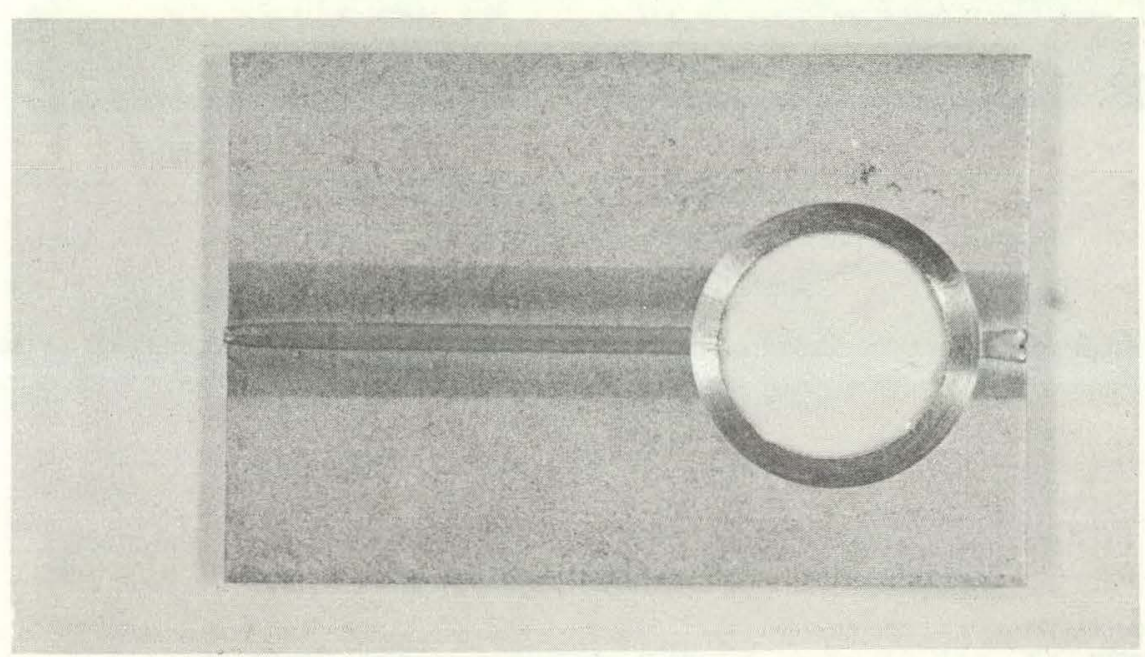

(a) Typical weld face. Magnification 1X.

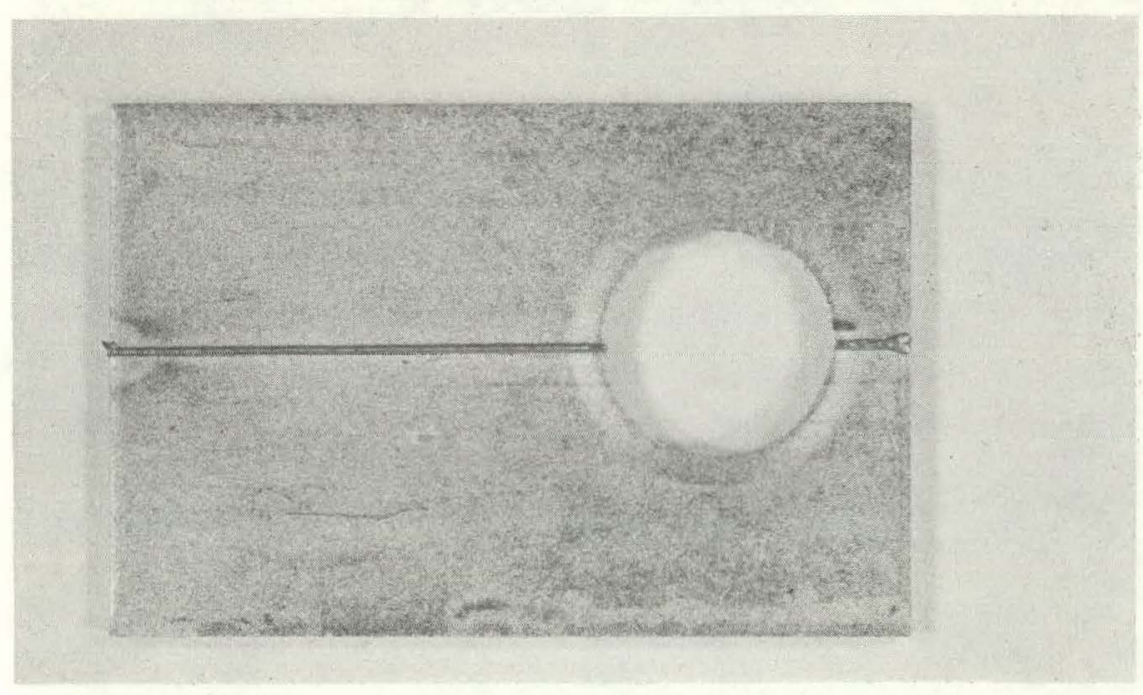




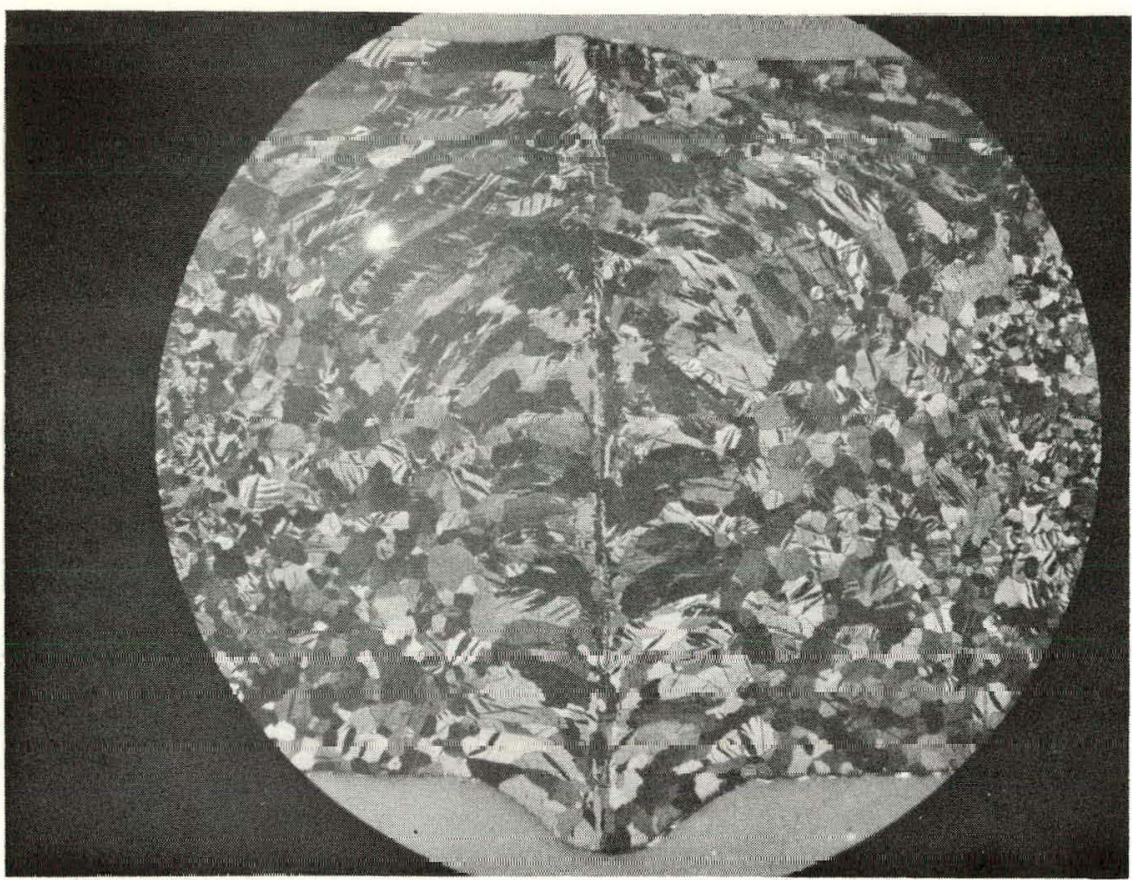

FIGURE 3. Photomicrograph of Weld in 2.5-mm Thick Material A. Parameters: $110 \mathrm{kV} ; 7.5 \mathrm{~mA} ; 8.5 \mathrm{~mm} / \mathrm{sec} . ; 400^{\circ} \mathrm{C}$ preheat. Magnification $25 \mathrm{X}$.

FIGURE 4. Photomicrograph of Weld in $2.5-\mathrm{mm}$ Thick Material B. Parameters: $110 \mathrm{kV} ; 7.5 \mathrm{~mA} ; 8.5 \mathrm{~mm} / \mathrm{sec} . ; 400^{\circ} \mathrm{C}$ preheat. Magnification $25 \mathrm{X}$

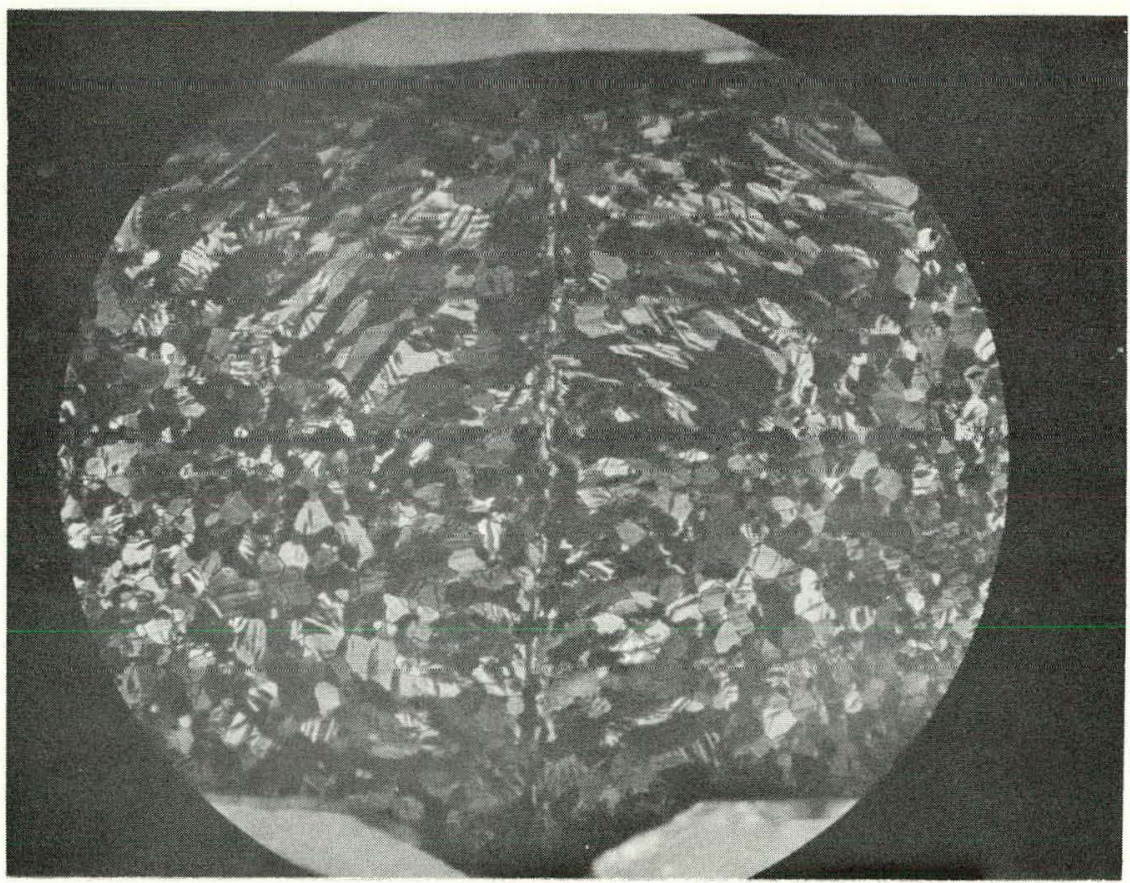


RFP-2621

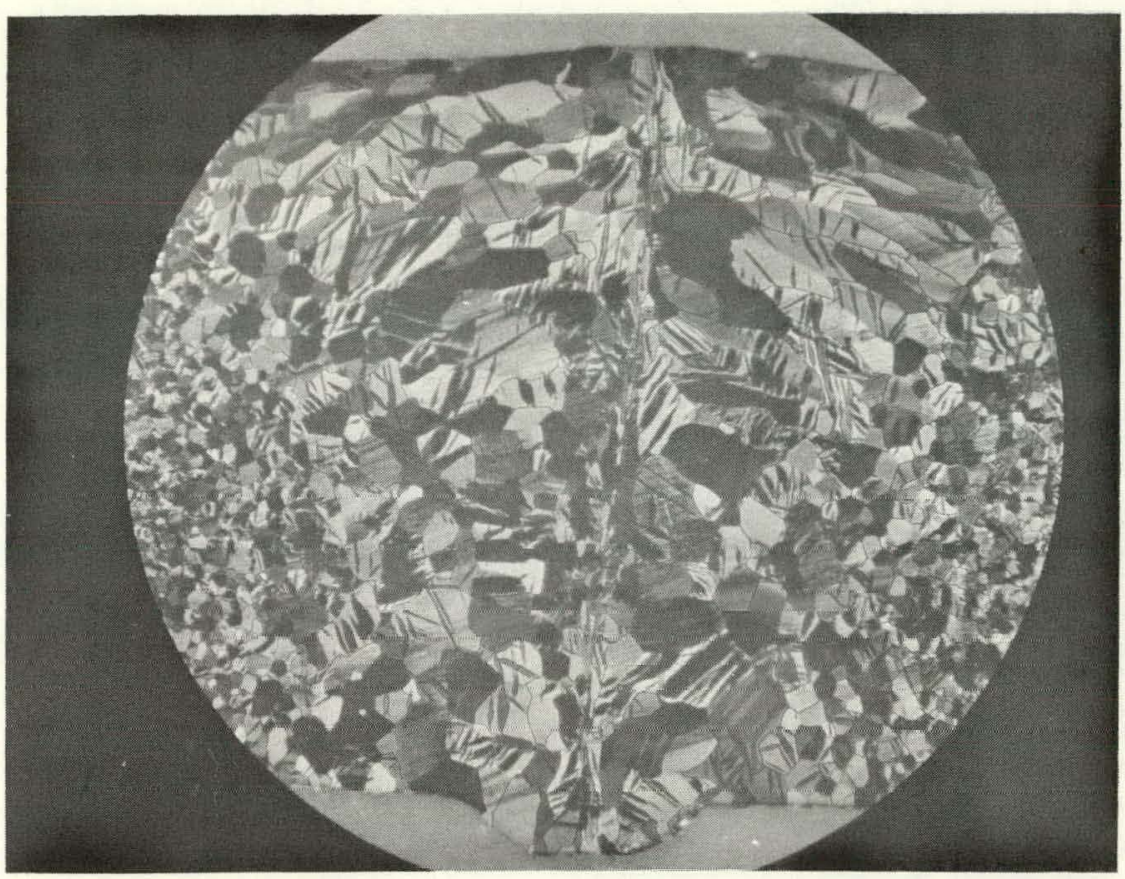

FIGURE 5. Photomicrograph of Weld in $2.5-\mathrm{mm}$ Thick Material C. Parameters: $110 \mathrm{kV} ; 7.5 \mathrm{~mA} ; 8.5 \mathrm{~mm} / \mathrm{sec} . ; 40{ }^{\circ} \mathrm{C}$ preheat. Magnification $25 \mathrm{X}$.

FIGURE 6. Photomicrograph of Weld in 1.4-mm Thick Material A. Parameters: $90 \mathrm{kV} ; 5 \mathrm{~mA} ; 8.5 \mathrm{~mm} / \mathrm{sec}$; $175^{\circ} \mathrm{C}$ preheat. Magnification $40 \mathrm{X}$.

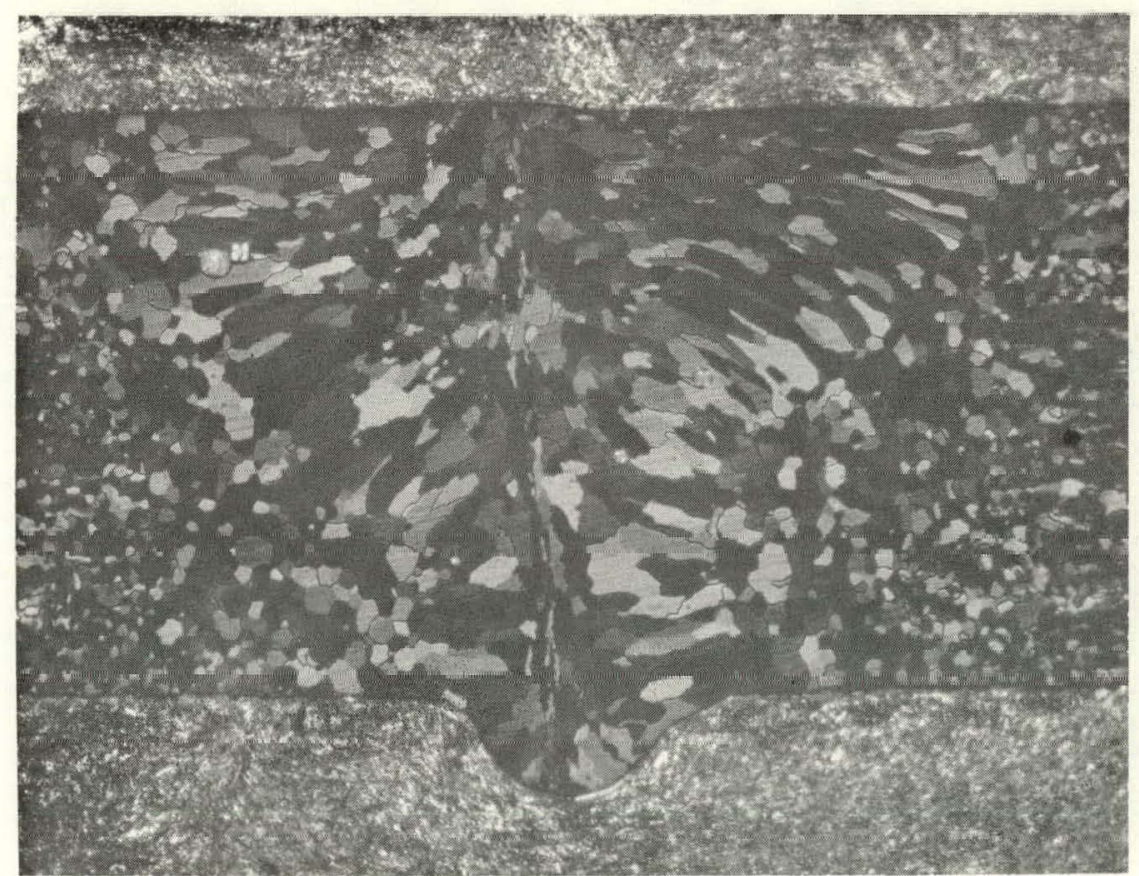


RFP-2621.

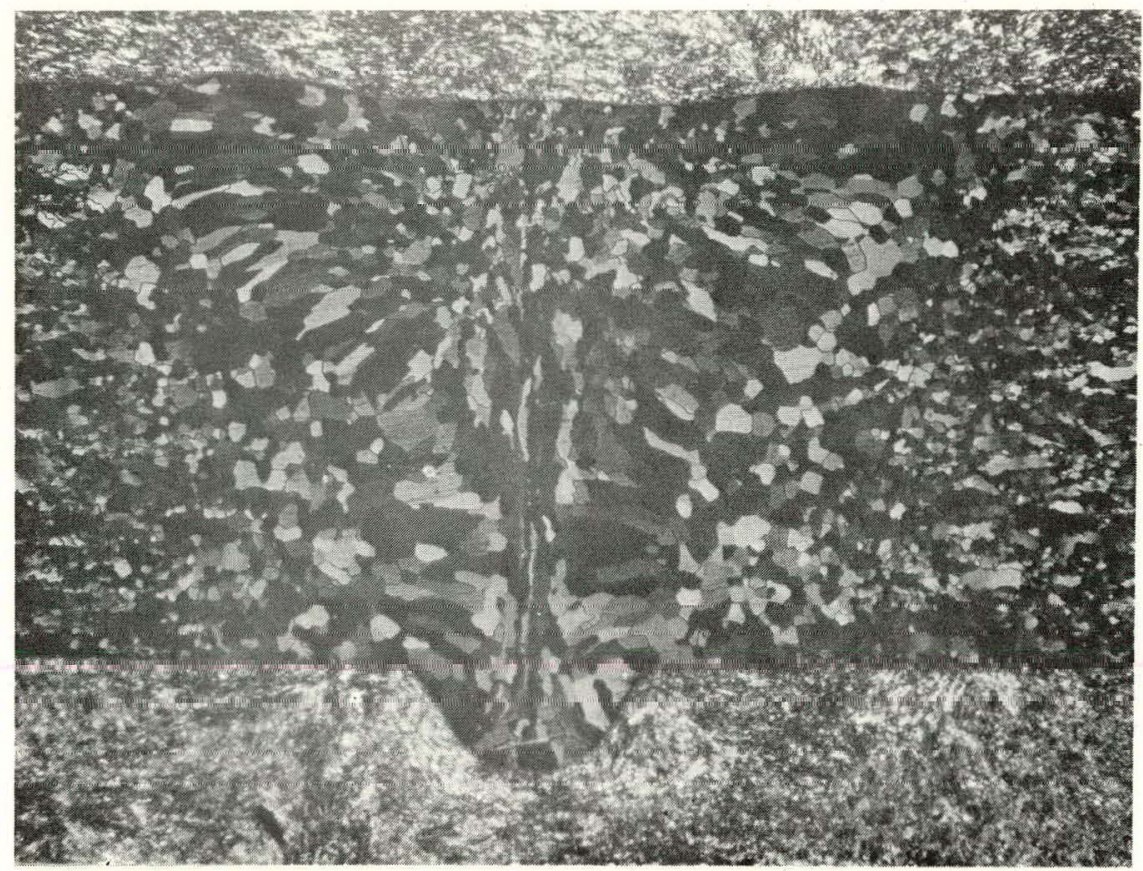

FIGURE 7. Photomicrograph of Weld in 1.4-mm Thick Material B. Parameters: $90 \mathrm{kV} ; 5 \mathrm{~mA} ; 8.5 \mathrm{~mm} / \mathrm{sec}$.; $175^{\circ} \mathrm{C}$ preheat. Magnification $40 \mathrm{X}$.

FIGURE 8. Photomicrograph of Weld in 1.4-mm Thick Material C. Parameters: $90 \mathrm{kV} ; 5 \mathrm{~mA} ; 8.5$ $\mathrm{mm} / \mathrm{sec}$; room temperature preheat. Weld is normal to tinal rolling direction. Magnitication 40X.

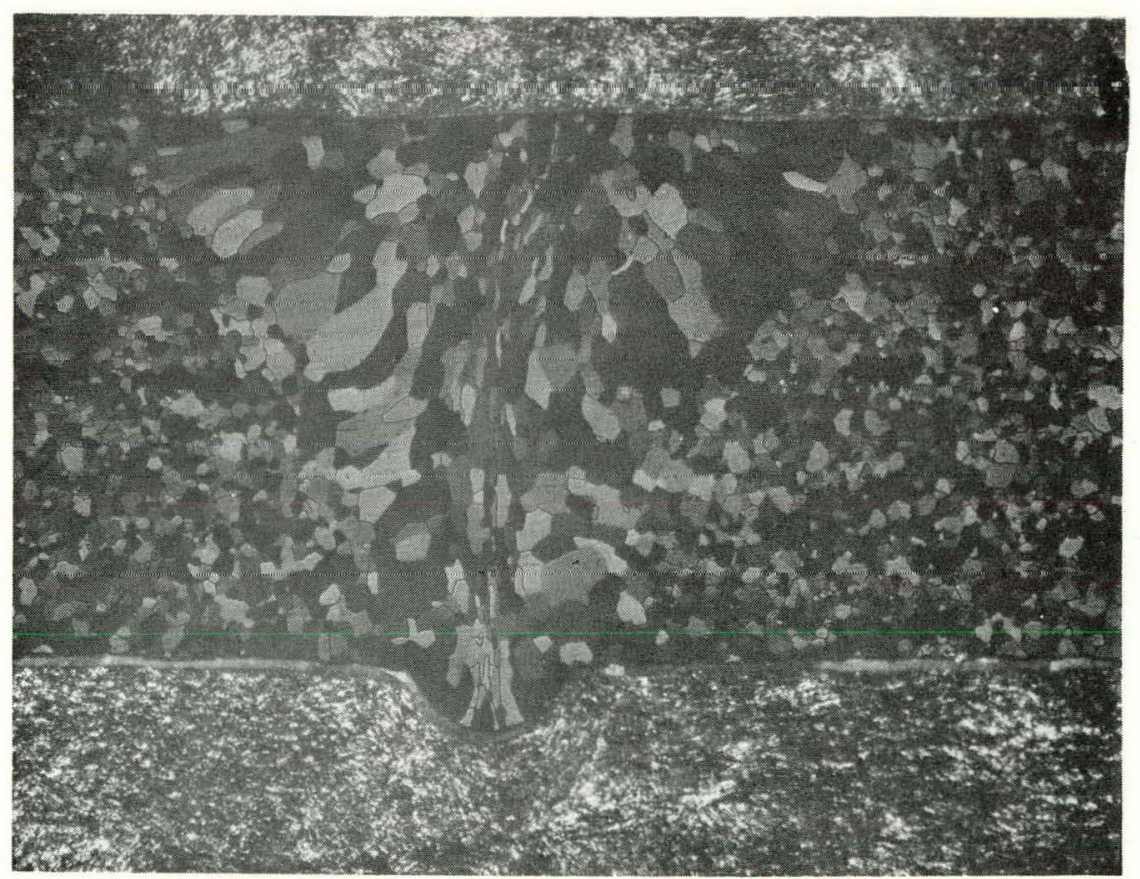


FIGURE 9. Photomicrograph of a Transverse Fusion-Zone Crack. Magnification 25X.

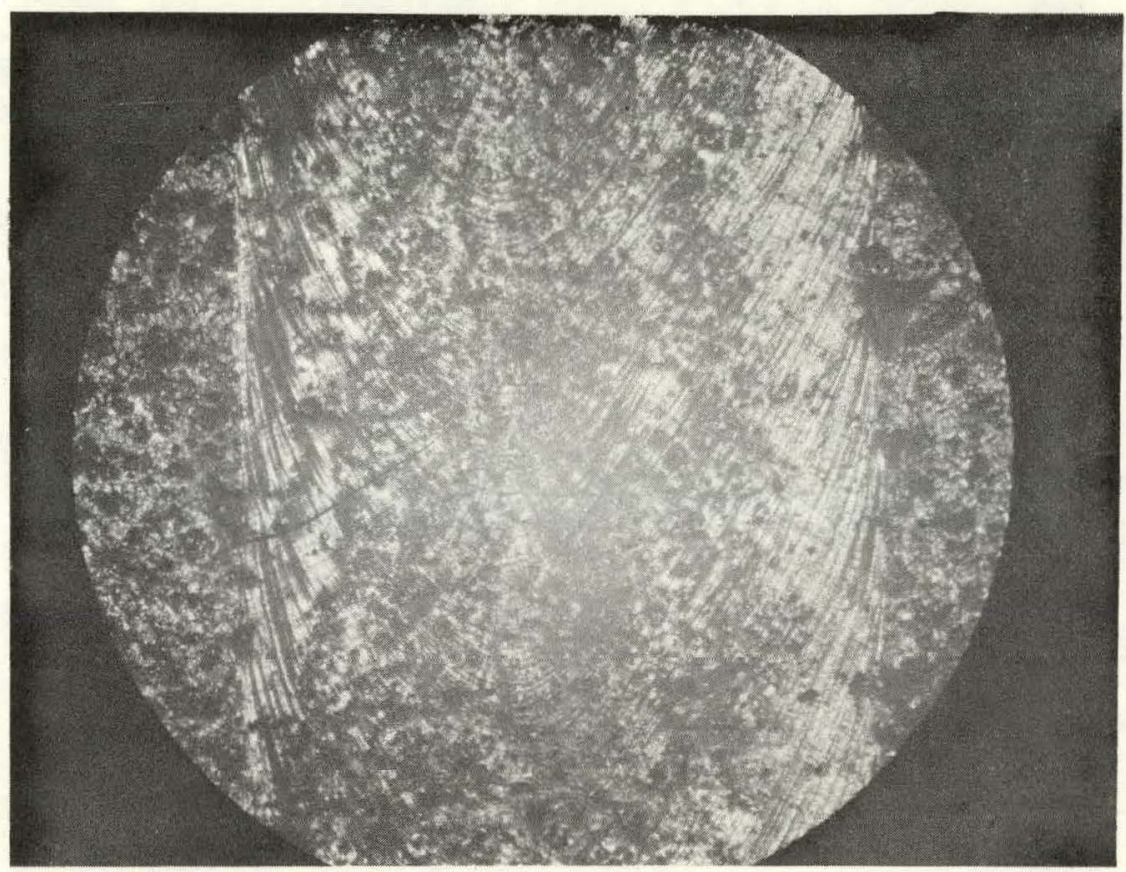


FIGURE 10(a), (b), and (c). Microstructure of As-Rolled Materials A, B, and C.

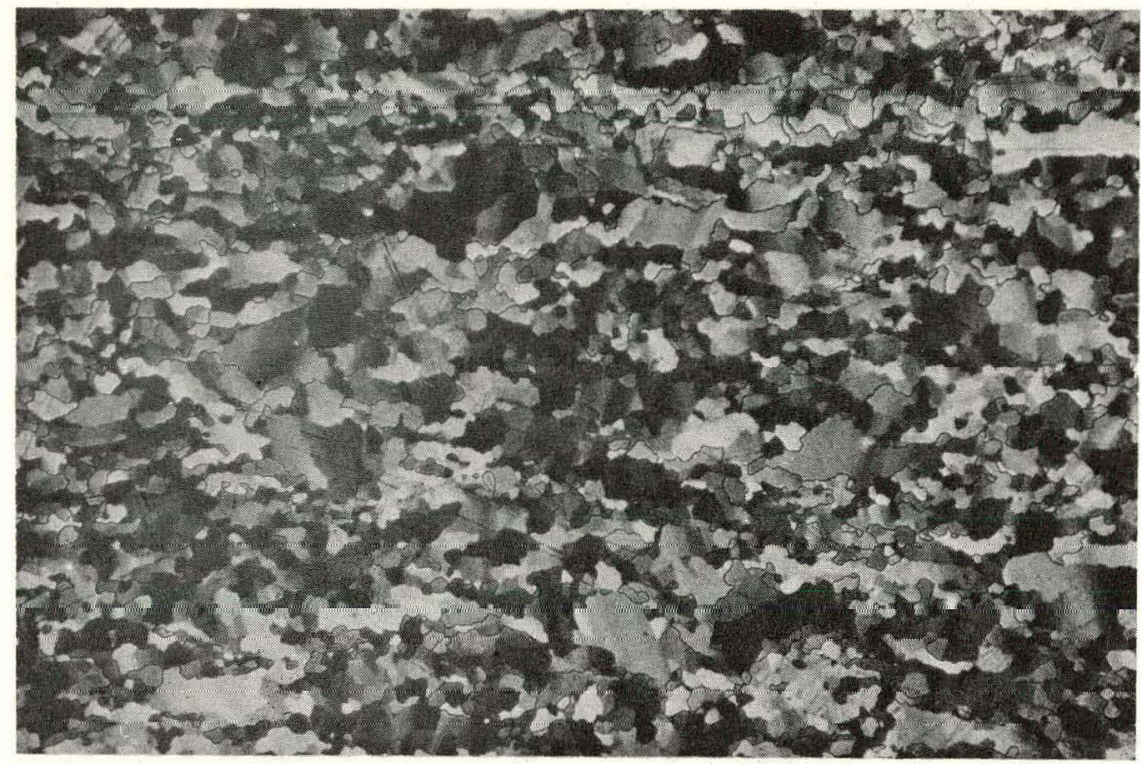

(a) Material A

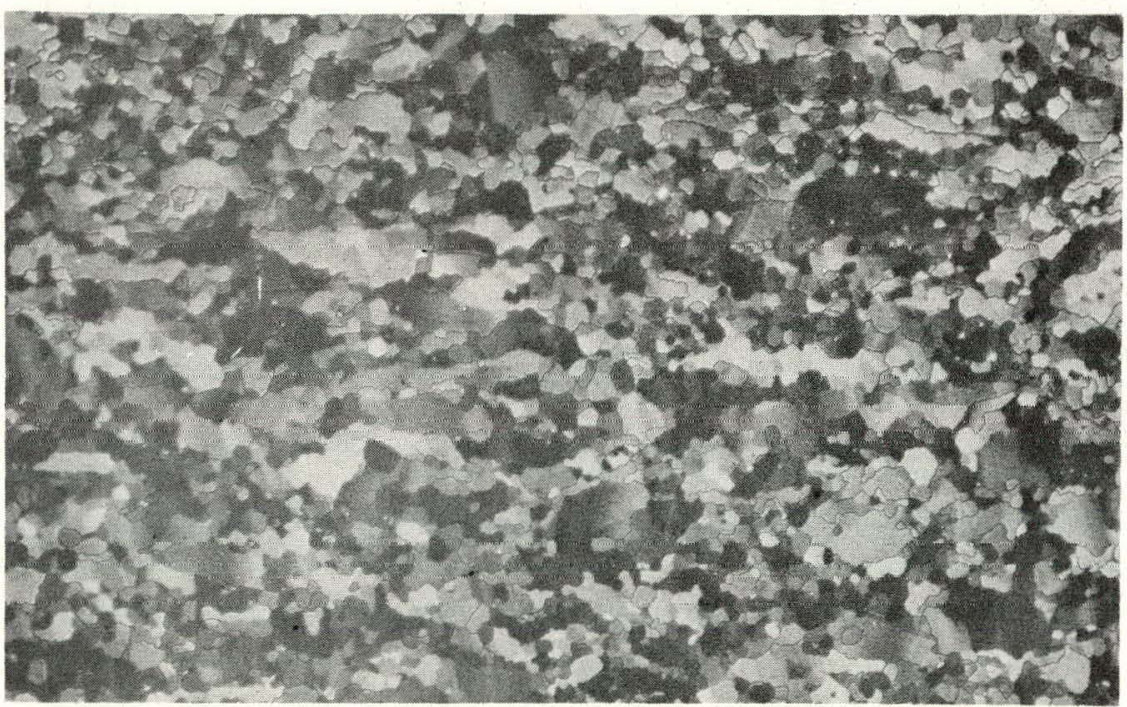

(b) Material B

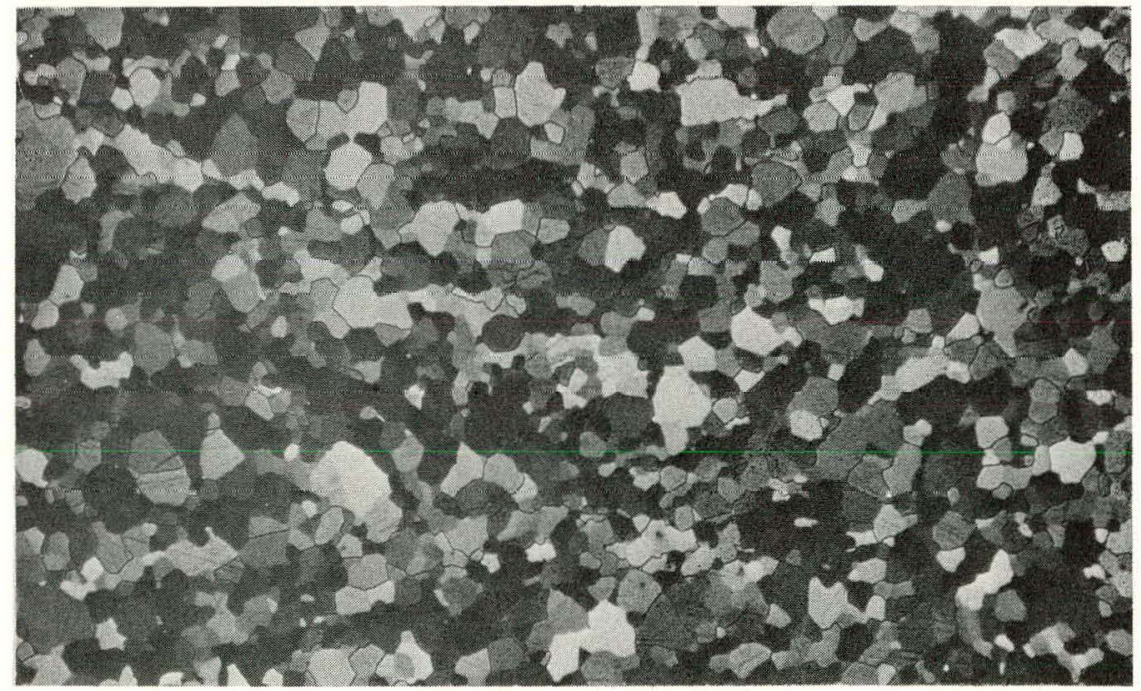

(c) Material C 
FIGURE 11(a), (b), and (c). Microstructure of Heat-Treated Materials A, B, and C.

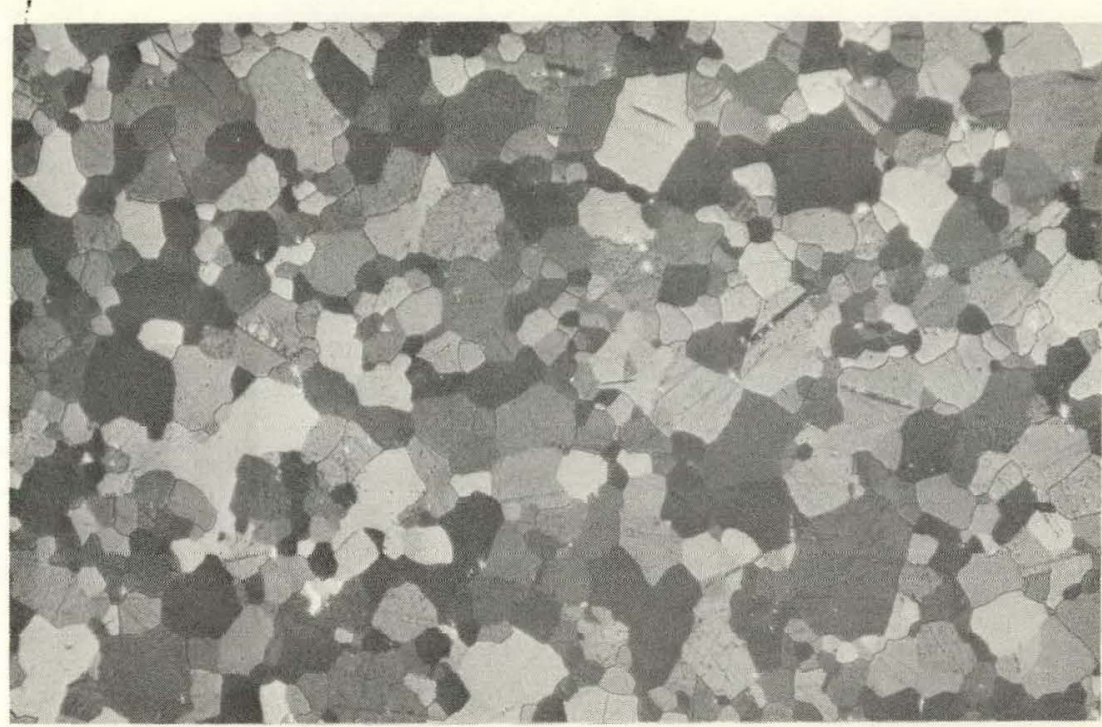

(a) Material A

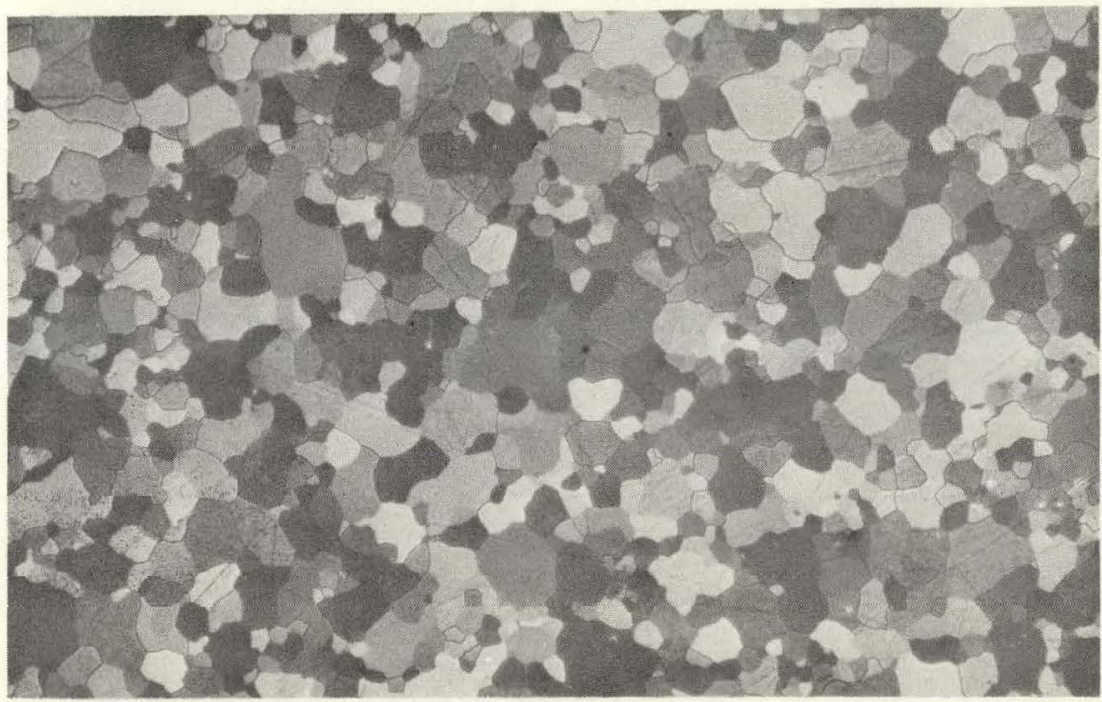

(b) Material B

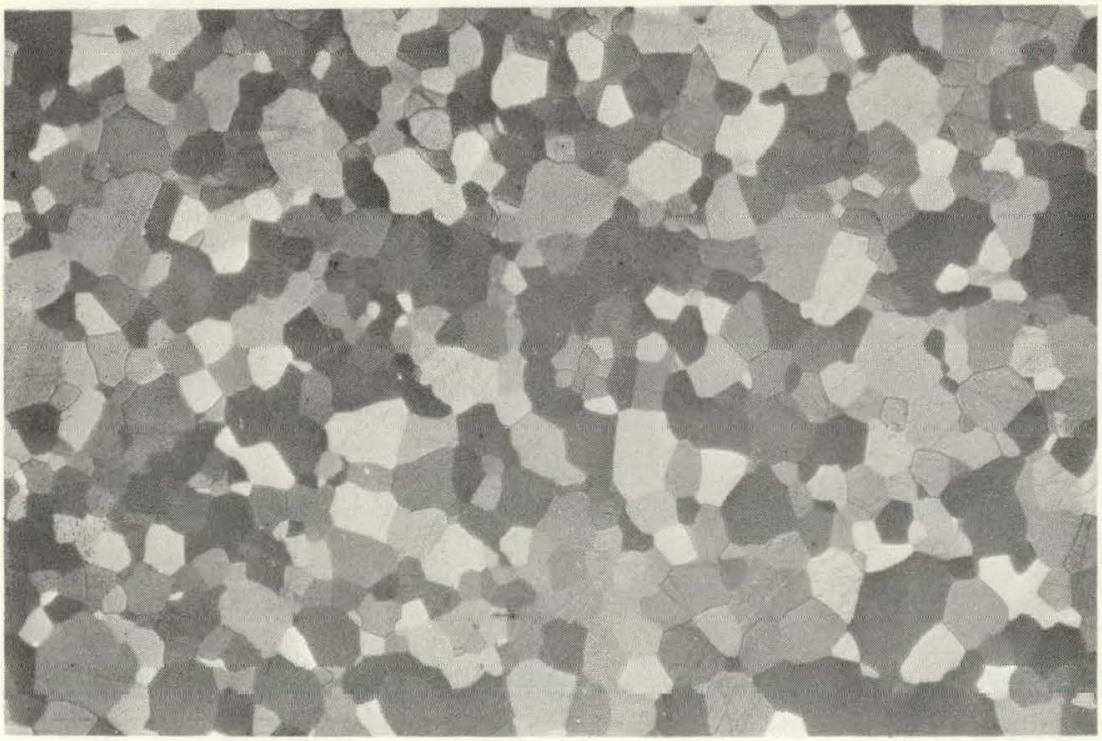

(c) Material C 
FIGURE 12. Ultimate Tensile Strength of AsRolled and Welded Specimens as a Function of Chemistry, Testing Temperature, and Preheat.

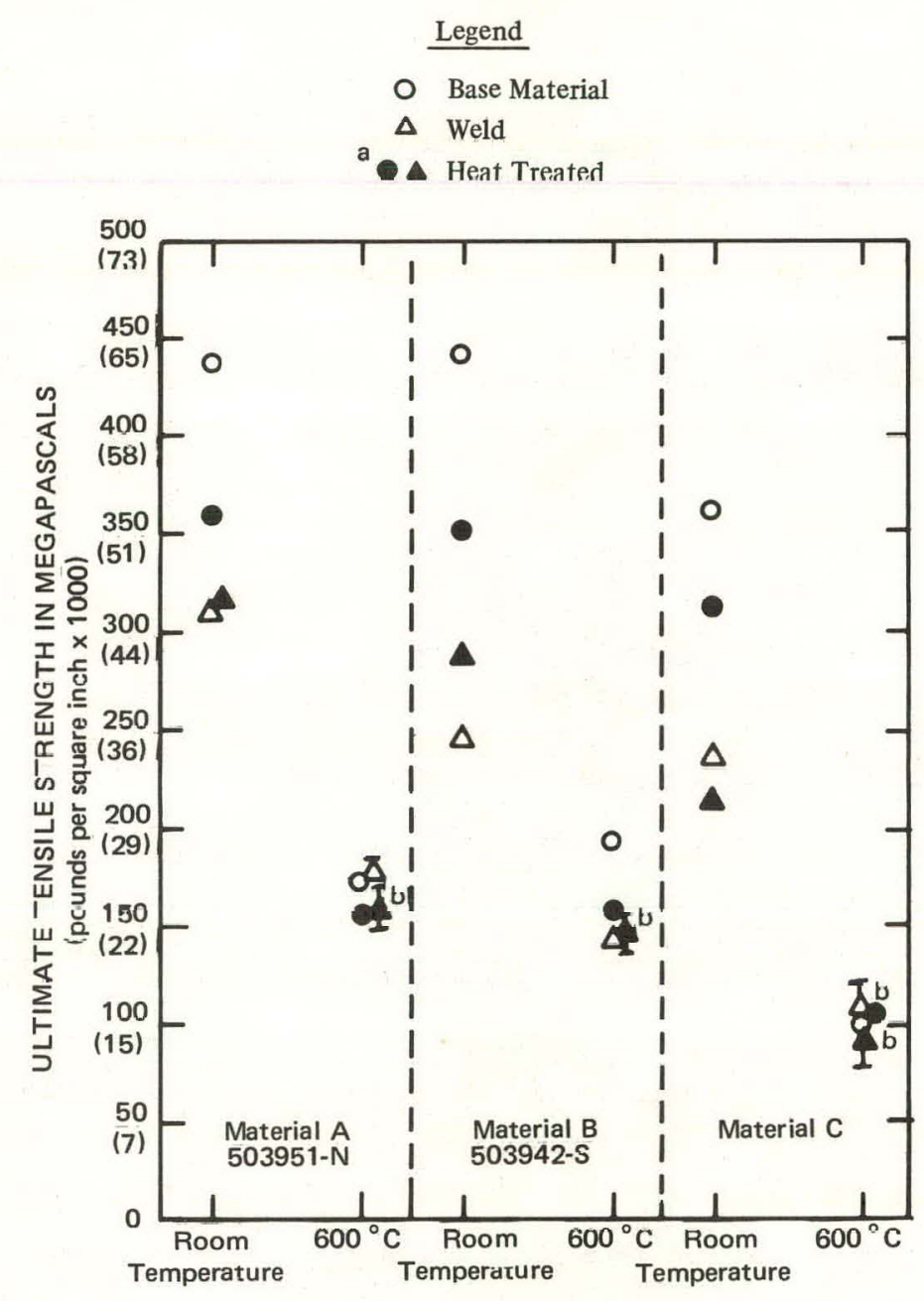

a Material A and B: 4 hours at $780^{\circ} \mathrm{C}$. Material C: 4 hours at $727^{\circ} \mathrm{C}$.

byariance is not shown if very small or if only one test was made. 


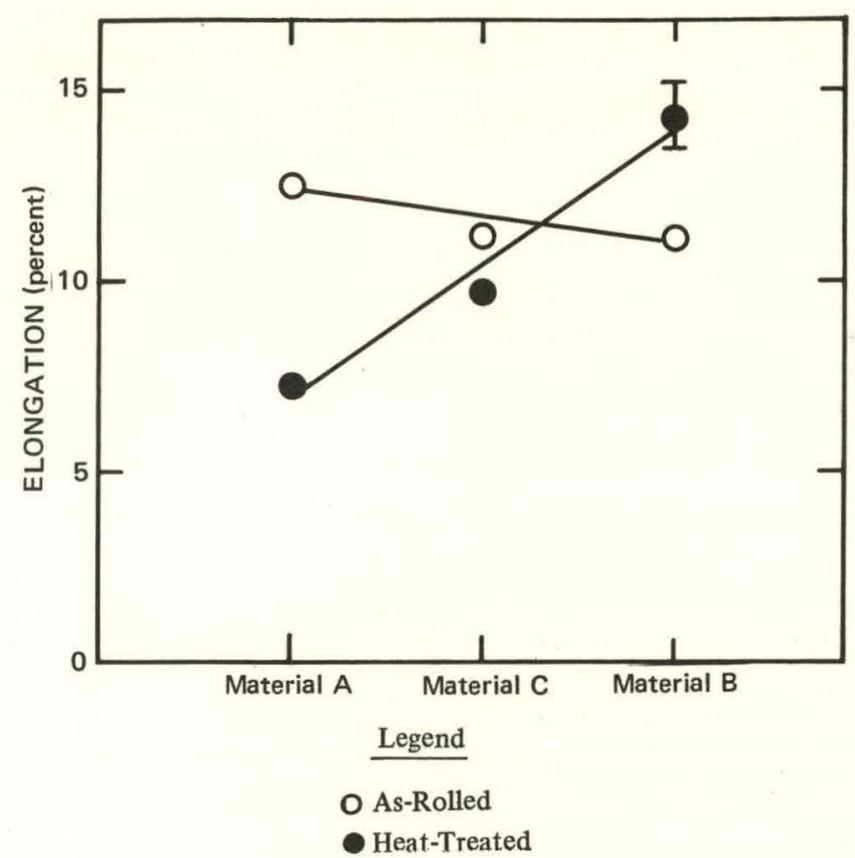

FIGURE 13. Room Temperature Ductility of As-Rolled and Heat-Treated Specimens as a Function of Composition.

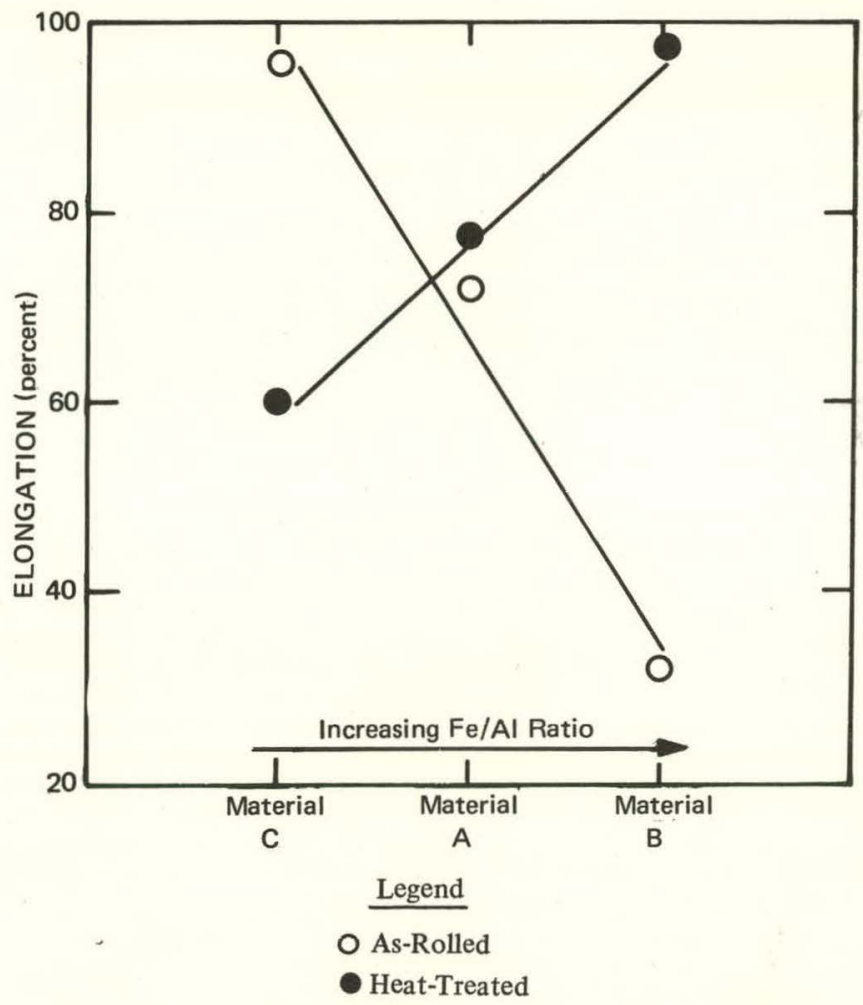

FIGURE 14. High Temperature Ductility of As-Rolled and Heat-Treated Specimens as a Function of Composition.

FIGURE 15. Room Temperature Ductility of Welded and Heat-Treated Specimens as a Function of Composition.

Legend

$\Delta$ As-Welded

$\Delta$ Heat-Treated

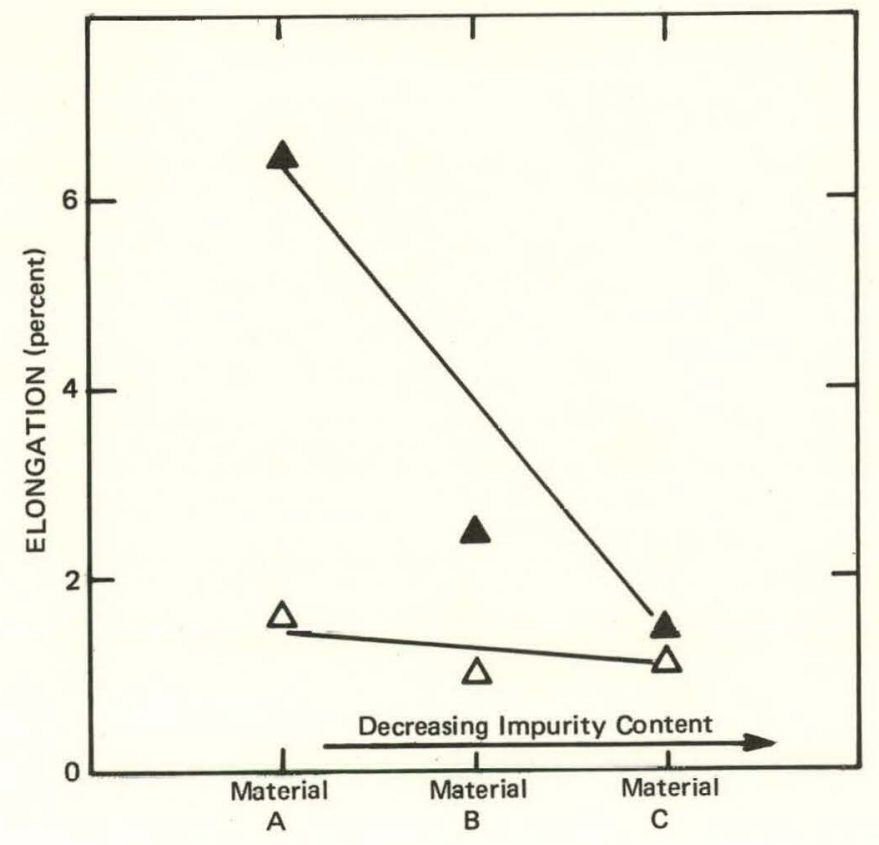




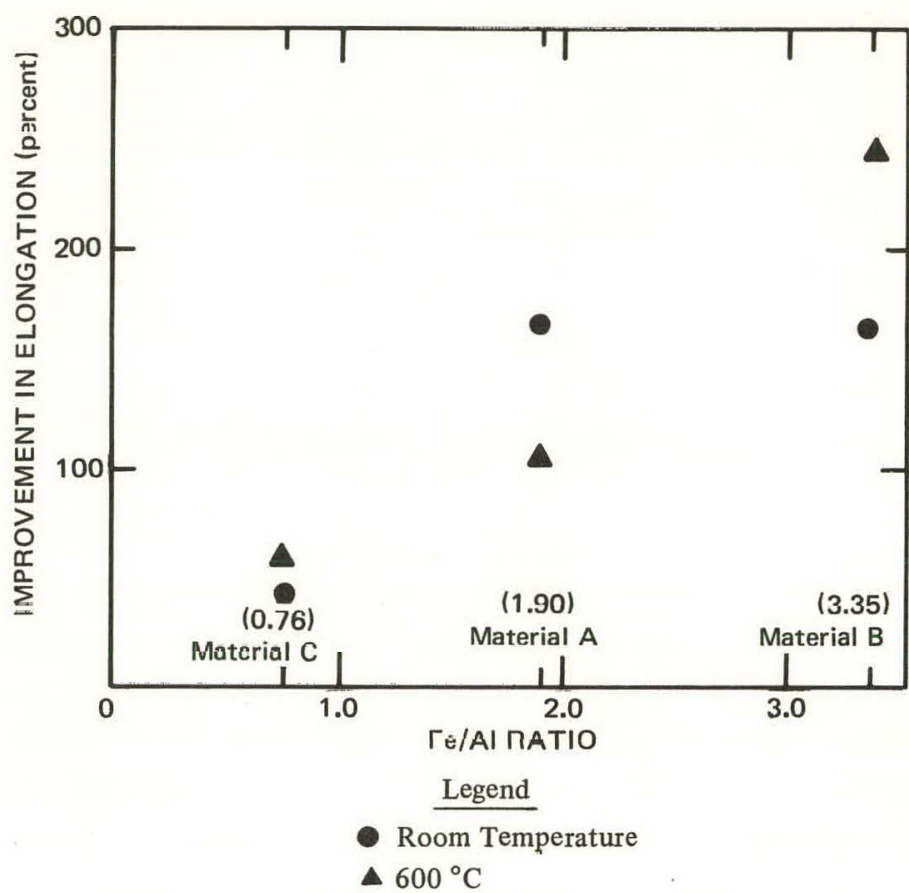

FIGURE 16. Improvement in Ductility as a Function of Iron to Aluminum Ratio for Room- and High-Temperature Tests.

FIGURE 17. High Temperature Ductility of Weled and Heat-Treated Specimens as a Function of Composition.

Legend

$\Delta$ As Welded

$\Delta$ Heat-Treated

a Base Metal Failure

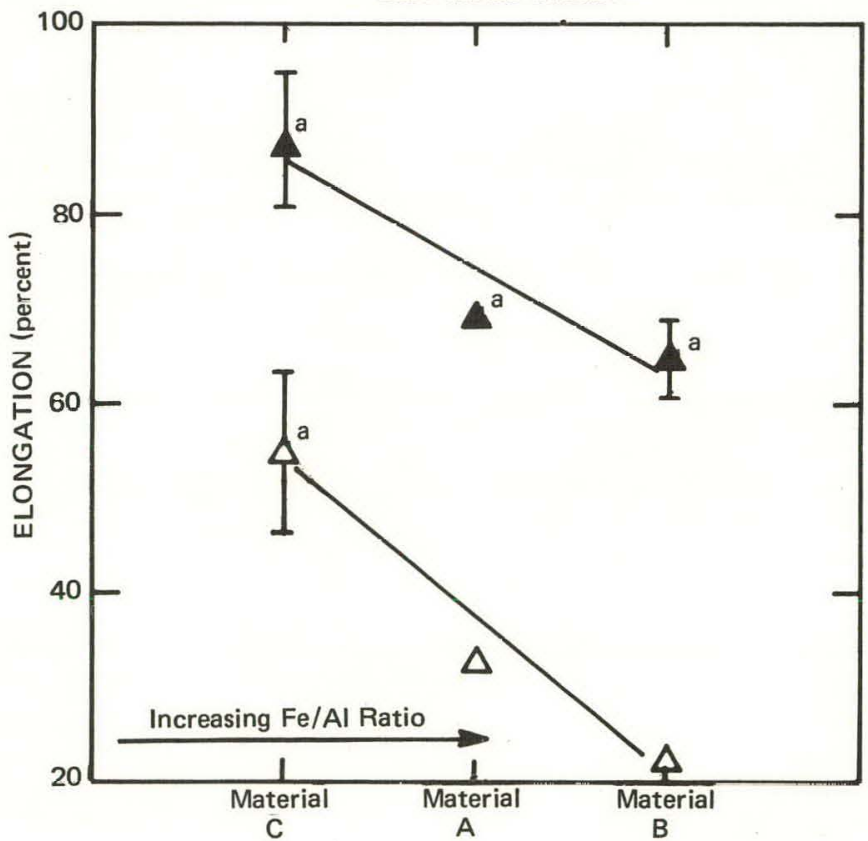




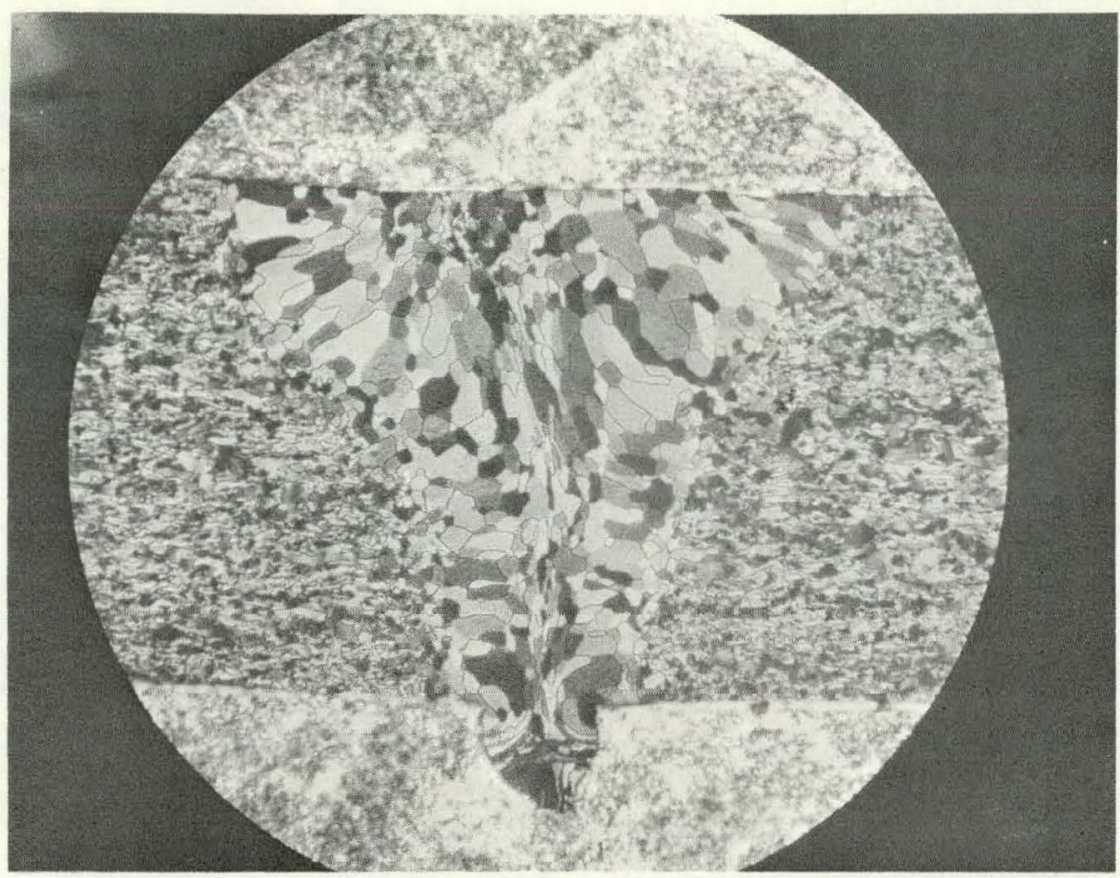

FIGURE 18. Photomicrograph of Weld in 1.9-mm Thick Material C. Parameters: $100 \mathrm{kV} ; 7 \mathrm{~mA} ; 8.5 \mathrm{~mm} / \mathrm{sec}$.; room temperature preheat. Magnification $25 \mathrm{X}$.

FIGURE 19. Photomicrograph of Weld in 1.9-mm Thick Material C. Parameters: $100 \mathrm{kV} ; 7 \mathrm{~mA} ; 8.5 \mathrm{~mm} / \mathrm{sec} . ; 175^{\circ} \mathrm{C}$ preheat. Magnification $25 \mathrm{X}$.

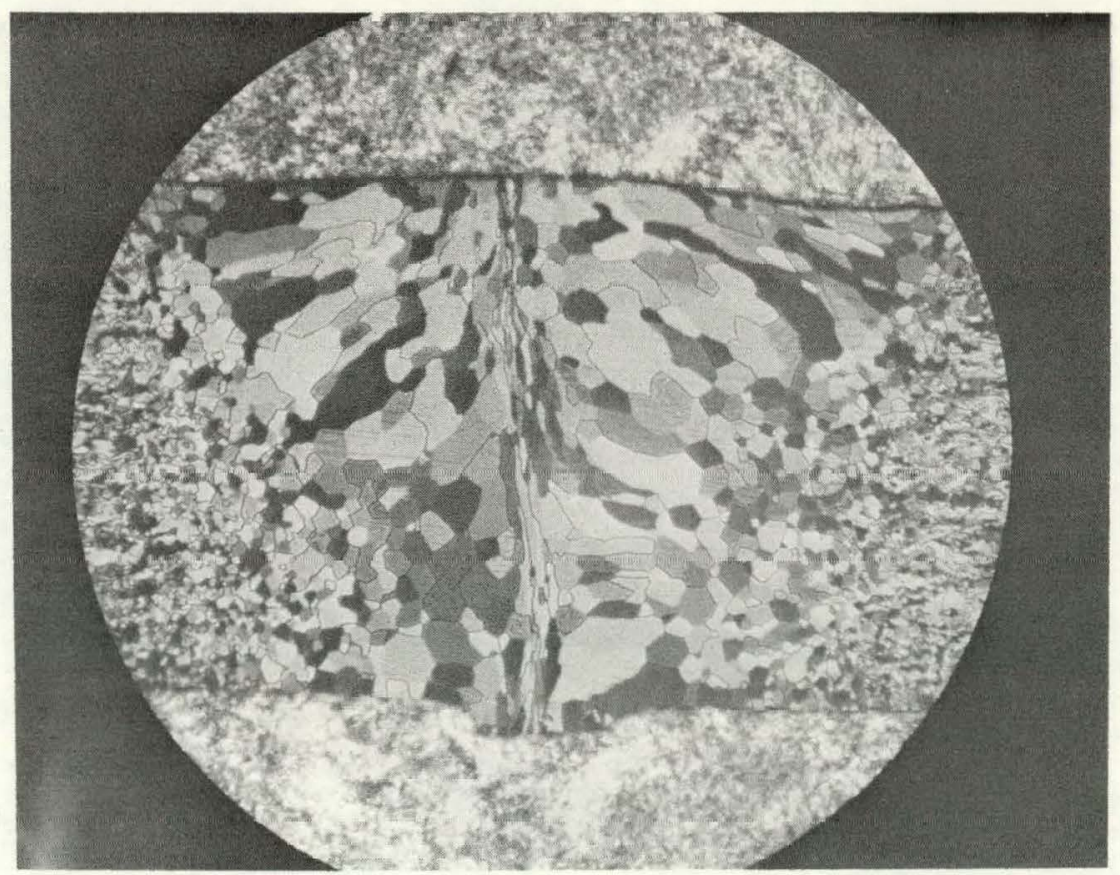




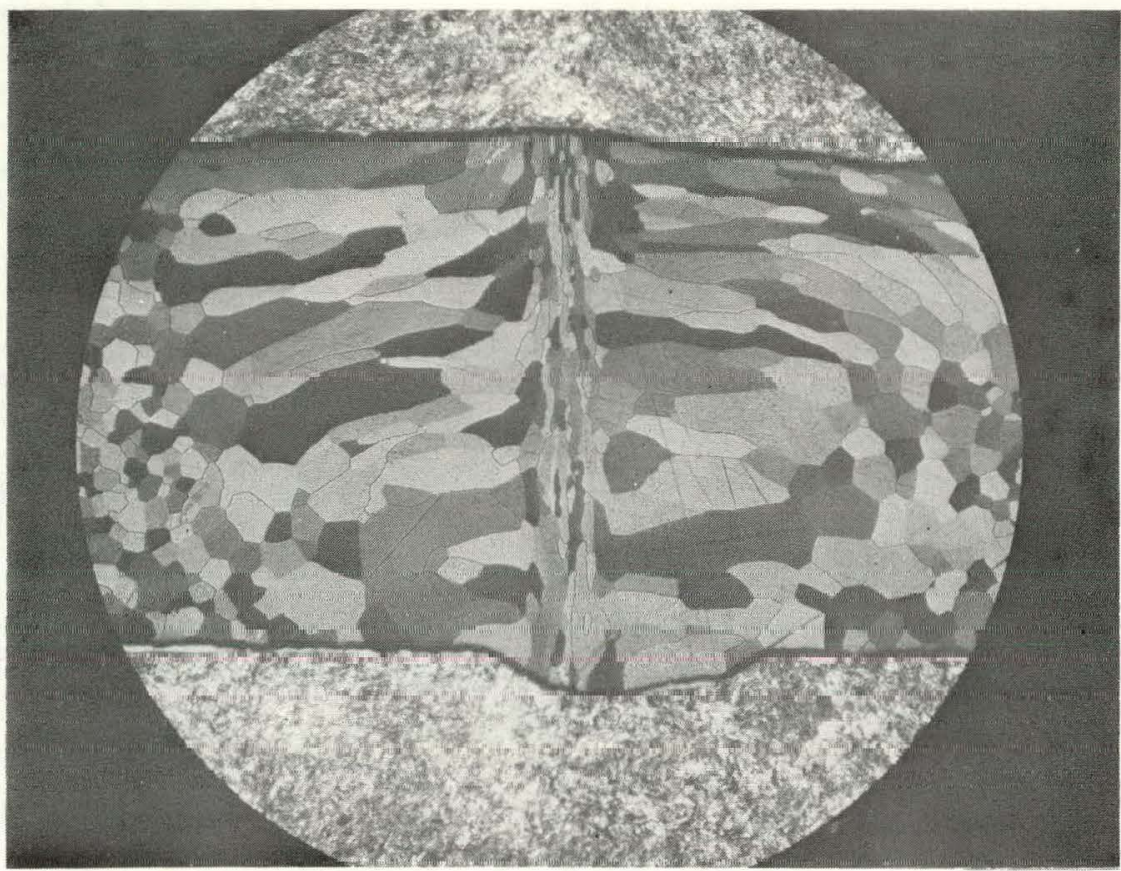

FIGURE 20. Photomicrograph of Weld in 1.9-mm Thick Material C. Parameters: $100 \mathrm{kV} ; 7 \mathrm{~mA} ; 8.5 \mathrm{~mm} / \mathrm{sec}$.; $400{ }^{\circ} \mathrm{C}$ preheat. Magnification $25 \mathrm{X}$.

FIGURE 21. Photomicrograph of Weld in 1.9-mm Thick Material C. Parameters: $100 \mathrm{kV} ; 5 \mathrm{~mA} ; 8.5 \mathrm{~mm} / \mathrm{sec} . ; 400{ }^{\circ} \mathrm{C}$ preheat. Magnification $25 \mathrm{X}$.

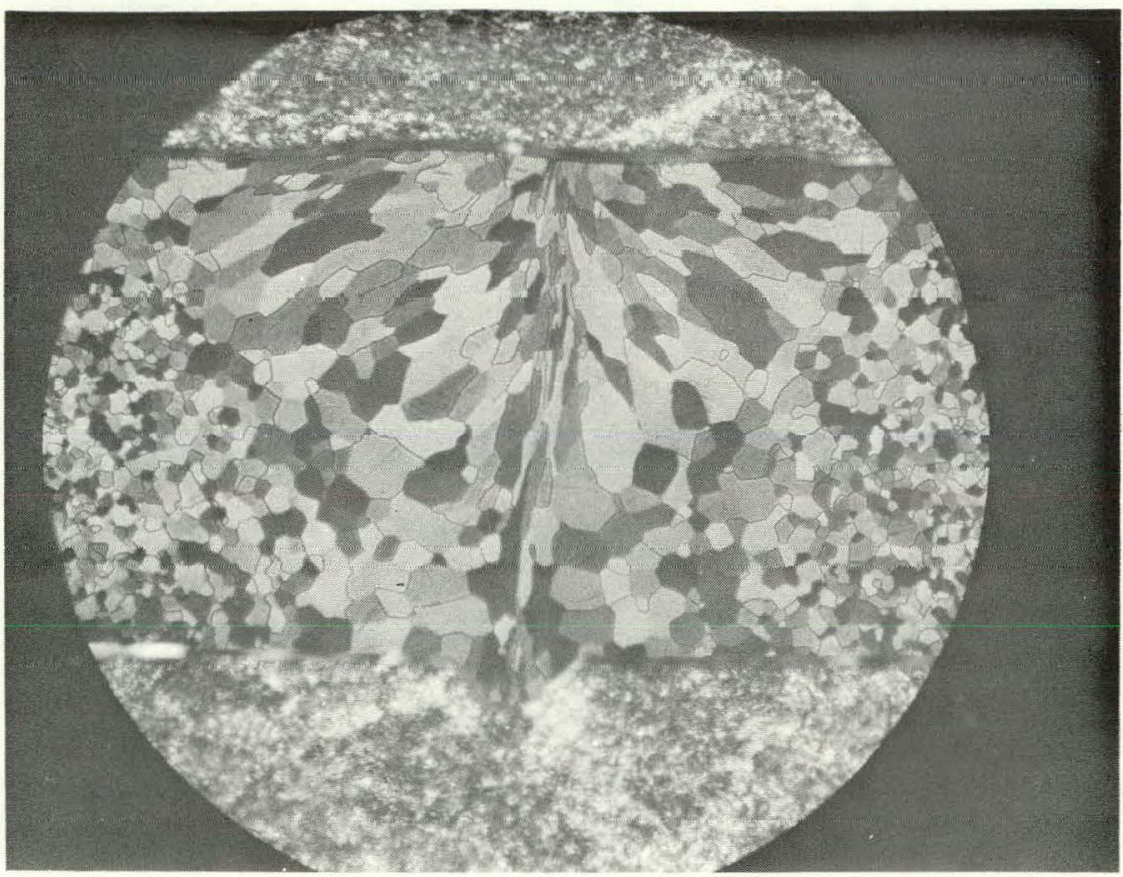




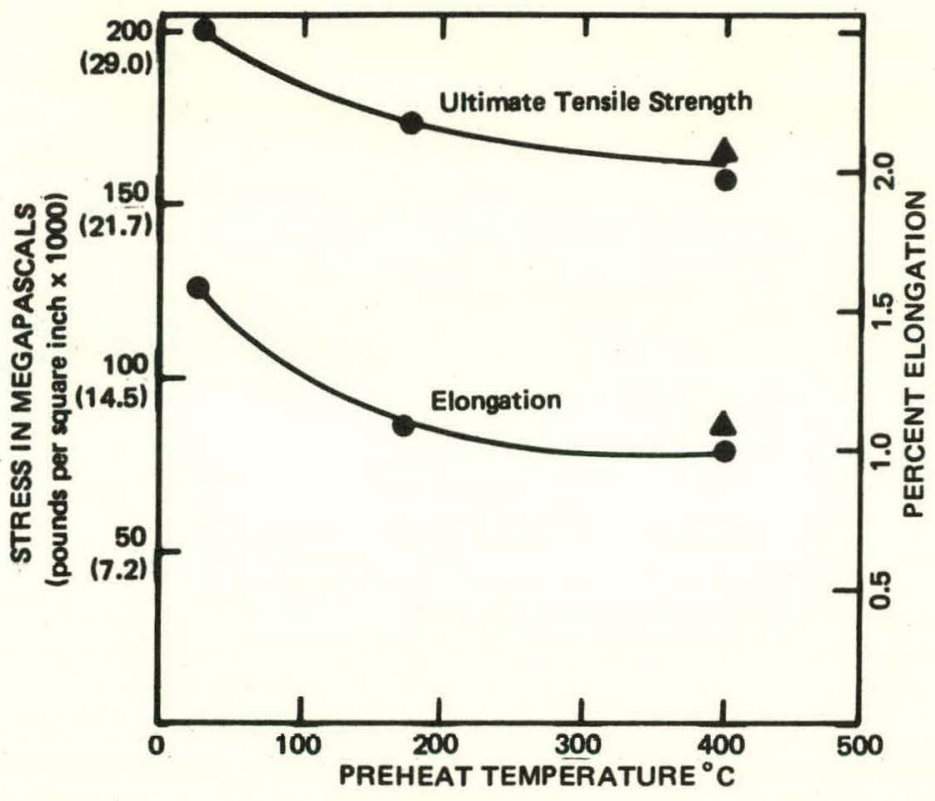

Legend

$100 \mathrm{kV}, 7 \mathrm{~mA}, 8.5 \mathrm{~mm} / \mathrm{sec}$.

$\Delta 100 \mathrm{kV}, 5 \mathrm{~mA}, 8.5 \mathrm{~mm} / \mathrm{sec}$.

FIGURE 22. Ultimate Tensile Strength and Ductility as a Function of Preheat and Welding Power.

FIGURE 23. Photomicrograph of Typical Fracture Path. Magnification 25X.

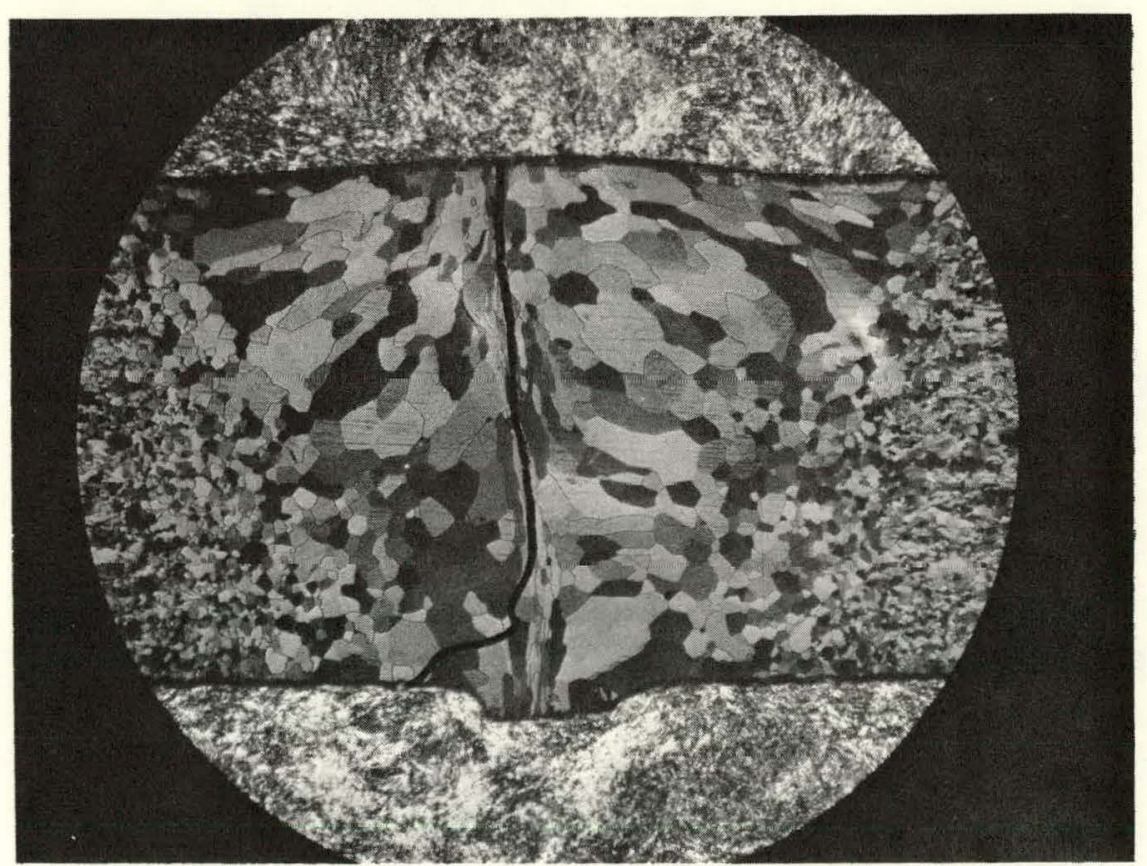


RFP-2621

\section{THIS PAGE WAS INTENTIONALLY LEFT BLANK}

